\title{
Menthol Alone Upregulates Midbrain nAChRs, Alters nAChR Subtype Stoichiometry, Alters Dopamine Neuron Firing Frequency, and Prevents Nicotine Reward
}

\author{
[Drandon J. Henderson, ${ }^{1}$ Teagan R. Wall, ${ }^{1}$ Beverley M. Henley, ${ }^{1}$ Charlene H. Kim, ${ }^{1}$ Weston A. Nichols, ${ }^{1}$ Ruin Moaddel, ${ }^{2}$ \\ (C)Cheng Xiao, ${ }^{1}$ and $\odot$ Henry A. Lester ${ }^{1}$ \\ ${ }^{1}$ Division of Biology and Biological Engineering, California Institute of Technology, Pasadena, California 91125, and ${ }^{2}$ National Institute on Aging, Baltimore, \\ Maryland 21224
}

\begin{abstract}
Upregulation of $\beta 2$ subunit-containing $\left(\beta 2^{\star}\right)$ nicotinic acetylcholine receptors (nAChRs) is implicated in several aspects of nicotine addiction, and menthol cigarette smokers tend to upregulate $\beta 2^{\star}$ nAChRs more than nonmenthol cigarette smokers. We investigated the effect of long-term menthol alone on midbrain neurons containing nAChRs. In midbrain dopaminergic (DA) neurons from mice containing fluorescent nAChR subunits, menthol alone increased the number of $\alpha 4$ and $\alpha 6 \mathrm{nAChR}$ subunits, but this upregulation did not occur in midbrain GABAergic neurons. Thus, chronic menthol produces a cell-type-selective upregulation of $\alpha 4^{\star} \mathrm{nAChRs,} \mathrm{complement-}$ ing that of chronic nicotine alone, which upregulates $\alpha 4$ subunit-containing $\left(\alpha 4^{\star}\right)$ nAChRs in GABAergic but not DA neurons. In mouse brain slices and cultured midbrain neurons, menthol reduced DA neuron firing frequency and altered DA neuron excitability following $\mathrm{nAChR}$ activation. Furthermore, menthol exposure before nicotine abolished nicotine reward-related behavior in mice. In neuroblastoma cells transfected with fluorescent $\mathrm{nAChR}$ subunits, exposure to $500 \mathrm{~nm}$ menthol alone also increased $\mathrm{nAChR}$ number and favored the formation of $(\alpha 4)_{3}(\beta 2)_{2} \mathrm{nAChRs}$; this contrasts with the action of nicotine itself, which favors $(\alpha 4)_{2}(\beta 2)_{3} \mathrm{nAChRs}$. Menthol alone also increases the number of $\alpha 6 \beta 2$ receptors that exclude the $\beta 3$ subunit. Thus, menthol stabilizes lower-sensitivity $\alpha 4^{*}$ and $\alpha 6$ subunitcontaining nAChRs, possibly by acting as a chemical chaperone. The abolition of nicotine reward-related behavior may be mediated through menthol's ability to stabilize lower-sensitivity nAChRs and alter DA neuron excitability. We conclude that menthol is more than a tobacco flavorant: administered alone chronically, it alters midbrain DA neurons of the nicotine reward-related pathway.
\end{abstract}

Key words: dopamine neuron; electrophysiology; menthol; nicotine; nicotinic receptor; reward

Significance Statement

Menthol, the most popular flavorant for tobacco products, has been considered simply a benign flavor additive. However, as we show here, menthol alone exerts several neurobiological changes. We are among the first to show that menthol, by itself, increases the number of nicotinic acetylcholine receptors (nAChRs) in the mouse brain. It does so at a dose that matches nicotine in its ability to increase nAChR number. At this same dose, menthol also alters midbrain dopamine neuron function and prevents nicotine reward-related behavior. Together, our data show that menthol is more than an "inert" flavor additive and is able to change the function of midbrain dopamine neurons that are part of the mesolimbic reward pathway.

\section{Introduction}

Tobacco use is the leading preventable cause of death in the United States (World Health Organization, 2008). Nicotine, the

\footnotetext{
Received Nov. 21, 2015; revised Jan. 19, 2016; accepted Jan. 29, 2016.

Author contributions: B.J.H., C.X., and H.A.L. designed research; B.J.H., T.R.W., B.M.H., C.H.K., and W.A.N. performed research; B.J.H., C.H.K., and R.M. contributed unpublished reagents/analytic tools; B.J.H., T.R.W., B.M.H., and W.A.N. analyzed data; B.J.H., B.M.H., C.X., and H.A.L. wrote the paper.

This work was supported by the National Institutes of Health (NIH; DA017279, DA019375, DA033721, DA036061, DA037161, and DA037743), the National Institute on Aging (NIH) Intramural Research Program, and the California Tobacco-Related Disease Research Program (17RT0127). We thank Michael Marks, Sharon Grady, and Ying Xie for menthol assays. We thank Heather Gold for help with bioinformatics.
}

primary addictive component of tobacco products, upregulates and changes the subunit stoichiometry of nicotinic acetylcholine receptors ( $\mathrm{nAChRs}$ ) containing the $\beta 2^{*}$ subunit ( $\beta 2^{*} \mathrm{nAChRs}$ ) in humans, nonhuman primates, and rodents, as well as in primary cultures and cell lines derived from these species (Breese et

\footnotetext{
The authors declare no competing financial interests.
}

Correspondence should be addressed to Henry A. Lester, California Institute of Technology, Division of Biology and Biological Engineering, 1200 E. California Blvd., MC 156-29, Pasadena, CA 91125-2900. E-mail: Lester@Caltech.edu.

DOI:10.1523/JNEUROSCI.4194-15.2016

Copyright $\odot 2016$ the authors $\quad 0270-6474 / 16 / 362957-18 \$ 15.00 / 0$ 
al., 1997; Nashmi et al., 2007; Mukhin et al., 2008; Lester et al., 2009; Govind et al., 2012; Srinivasan et al., 2012; Brody et al., 2013; Henderson and Lester, 2015). Although midbrain dopaminergic (DA) neurons dominate the nicotine reward-related pathway, chronic nicotine does not change the $\alpha 4$ subunit-containing $\left(\alpha 4^{\star}\right)$ nAChR number in DA neurons of the ventral tegmental area (VTA) or substantia nigra pars compacta (SNc) but upregulates $\alpha 4^{\star}$ nAChRs in the GABAergic neurons of the substantia nigra pars reticulata (SNr; Nashmi et al., 2007; Xiao et al., 2009). $\alpha 6$ Subunit-containing $\left(\alpha 6^{*}\right)$ nAChRs in DA neurons of the VTA and $\mathrm{SNc}$ are upregulated by chronic nicotine (Henderson et al., 2014). These changes result in increased inhibitory tone from SNr GABAergic neurons and decreased firing frequency of VTA and SNc DA neurons (Nashmi et al., 2007; Xiao et al., 2009). In consequence, disinhibition and enhanced excitation lead to enhanced DA neuron burst firing and enhanced DA release (Sulzer, 2011; Faure et al., 2014). These changes are likely a primary contributor to nicotine dependence.

Menthol is the sole remaining flavor additive that is allowed in cigarettes, and "menthol cigarettes" are used by a third of all smokers and a majority of African-American smokers ( $~ 84 \%$; McCarthy et al., 1995). Recently, it was revealed that almost all cigarettes contain menthol even if they are not explicitly labeled as such (Ai et al., 2015). Smokers of menthol cigarettes exhibit more $\beta 2^{\star} \mathrm{nAChR}$ upregulation in several brain regions compared with nonmenthol smokers (Brody et al., 2013). It is unclear whether this additional upregulation occurs because menthol enhances nicotine's pharmacology, alters the metabolism of nicotine, or acts independently. Of note, smokers of menthol cigarettes have more difficulty quitting when compared with smokers of nonmenthol cigarettes (Gandhi et al., 2009).

Menthol is a negative allosteric modulator of $\alpha 4 \beta 2 \mathrm{nAChRs}$ and a noncompetitive antagonist of $\alpha 7$ and $\alpha 3 \beta 4 \mathrm{nAChRs,} \mathrm{with}$ $\mathrm{IC}_{50}$ values of $\sim 111, \sim 35$, and $\sim 70 \mu \mathrm{M}$ respectively (Hans et al., 2012; Ashoor et al., 2013; Ton et al., 2015). These concentrations probably exceed those found in vivo (Benowitz et al., 2004) and may not explain the observations of Brody et al. (2013). It is also suggested that menthol decreases airway irritation, and allows smokers to inhale more nicotine; or menthol may slow the metabolism of nicotine, allowing elevated concentrations of nicotine in the plasma (Benowitz et al., 2004; Alsharari et al., 2015). Nevertheless, some still suggest that menthol's ability to alter nicotine metabolism may not be sufficient to increase plasma levels of nicotine (Ashley et al., 2012).

If menthol does increase nicotine in the plasma, this may be an insufficient explanation for enhanced upregulation observed in human menthol cigarette smokers (Brody et al., 2013). Human studies using 2-[ $\left.{ }^{18} \mathrm{~F}\right]$ fluoro-A-85380 (binds $\beta 2^{\star} \mathrm{nAChRs)} \mathrm{indi-}$ cate that $\beta 2^{\star} \mathrm{nAChR}$ upregulation in humans is saturated with only a few cigarettes smoked daily (Staley et al., 2006), probably because $\beta 2^{\star} \mathrm{nAChRs}$ are saturated even at nicotine concentrations found in low-nicotine cigarettes (Brody et al., 2009). Menthol may increase nicotine concentration in human blood by 20\% (Ahijevych and Garrett, 2004; Benowitz et al., 2004), and this may be insufficient to explain the menthol effect noted in humans (Brody et al., 2013). Thus, actions in the airways or in the liver may not fully explain the role of menthol in nicotine dependence. This led us to hypothesize that prolonged exposure to smoking-relevant levels of menthol may act independently of nicotine to change nAChRs. To address this hypothesis, we used a combination of in vivo and in vitro methods to characterize menthol's effect on nicotine reward-related behavior and on nAChR number, function, and stoichiometry.

\section{Materials and Methods}

Reagents. ( \pm )-Menthol (product \#63670), CI-976 (product \#C3743), acetylcholine chloride (product \#A6625), and (-)-nicotine hydrogen tartrate (product \#1463304) were obtained from Sigma-Aldrich. All nicotine concentrations listed (both molarity and milligrams per kilogram) use the "free base" convention (Matta et al., 2007), with a molecular weight for nicotine of $162.23 \mathrm{~g} / \mathrm{mol}$. Models 1002 and 1004 osmotic minipumps were obtained from Alzet.

Animals. All experiments were conducted in accordance with the guidelines for care and use of animals provided by the National Institutes of Health, and protocols were approved by the Institutional Animal Care and Use Committee at the California Institute of Technology. The $\alpha 6$ eGFP bacterial artificial chromosome (BAC) transgenic strain used in this study possessed six copies of the $\alpha 6$-eGFP BAC and has been described previously (Mackey et al., 2012; Henderson et al., 2014). The $\alpha 4$-mCherry knock-in mouse strain and the $\beta 3$-GFP nAChR knock-in mouse strain have been described previously (Shih et al., 2014; Srinivasan et al., 2016). The Gene Expression Nervous System Atlas (GENSAT) TH-eGFP strain (Gong et al., 2003) was purchased from the Mutant Mouse Regional Resource Center. All experiments using mice included both sexes in approximately equal numbers. In total, 71 mice were used to accumulate the data in this manuscript. Of those, 33 were male and 38 were female. No sex differences were noted.

Menthol dose selection. We studied effects of $( \pm)$-menthol (referred to as menthol from this point). We estimated the pharmacologically relevant dose of menthol by analogy with nicotine doses used in mouse studies. The typical menthol cigarette contains 1-20 mg of menthol (Ai et al., 2015) and $\sim 1 \mathrm{mg}$ of nicotine (Rodgman and Perfetti, 2009). Therefore, menthol per cigarette is $1-5$ times that of nicotine for the typical menthol cigarette, but up to 20 times greater for some menthol cigarette brands. Steady-state and peak concentrations of nicotine, as found in human smokers, are replicated in mice using 0.4 and $2.0 \mathrm{mg} / \mathrm{kg} / \mathrm{h}$ doses of nicotine, respectively (Matta et al., 2007). Conditioned place preference (CPP) assays use $0.5 \mathrm{mg} / \mathrm{kg}$ nicotine (Tapper et al., 2004). Assays for in vivo upregulation use $2.0 \mathrm{mg} / \mathrm{kg} / \mathrm{h}$ nicotine (Nashmi et al., 2007; Henderson et al., 2014). We selected $1 \mathrm{mg} / \mathrm{kg}$ and $2 \mathrm{mg} / \mathrm{kg} / \mathrm{h}$ menthol for CPP and in vivo upregulation assays, respectively (Figs. 1,2). Both dose selections fall within the 1:5 menthol/nicotine ratio of a typical "menthol cigarette."

In vitro experiments with mouse neuroblastoma $2 \mathrm{a}$ (Neuro-2a) cells and cultured midbrain neurons were performed with $500 \mathrm{~nm}$ menthol ( $24 \mathrm{~h}$ and $7-10 \mathrm{~d}$, respectively). We chose this concentration from preliminary menthol concentration-response studies. At $50 \mathrm{~nm}$ menthol, upregulation was less than at $500 \mathrm{~nm}$. At $5 \mu \mathrm{M}$ menthol, the data were too variable for systematic study. Therefore, $500 \mathrm{~nm}$ menthol provided the most consistent and robust upregulation response with nAChRs transiently expressed in Neuro-2a cells.

We attempted to determine the concentration of menthol in the mouse brain following our long-term exposure paradigm (see Figs. 1-4). An experimental assay that could detect menthol at concentrations $\geq 2.5$ $\mu \mathrm{M}$ in brain tissue was developed. When the assay was used on brains from mice implanted with osmotic minipumps, no measurable amount of menthol was detected. Therefore the menthol concentration in the brains was $<2.5 \mu \mathrm{M}$, and possibly much less.

Chronic drug administration with osmotic minipumps. Chronic menthol or vehicle was administered to mice using osmotic minipumps (model 1002, Alzet) following a procedure that has been reported previously (Henderson et al., 2014). Vehicle was $60 \%$ ethanol and $40 \%$ saline. Given the infusion rate of the osmotic minipumps $(0.25 \mu \mathrm{l} / \mathrm{h}), \sim 4.2$ $\mathrm{mg} / \mathrm{kg}$ ethanol was delivered to mice each hour for a total of $0.1 \mathrm{~g} / \mathrm{kg}$ in a $24 \mathrm{~h}$ period. This is $45-100$-fold below the dose that has been used to study the reinforcing effects of ethanol with C57BL/6 mice (Grahame and Cunningham, 1997). Because the control solutions in the osmotic minipumps also contained $60 \%$ ethanol, we have confidence that effects attributed to menthol in this study do not include effects of ethanol.

$C P P$ assays. An unbiased protocol was used, where nicotine $(0.5 \mathrm{mg} /$ $\mathrm{kg}$ ) was given in the white chamber on "drug" days and saline was given in the black chamber. A standard three-chamber rectangular cage was 

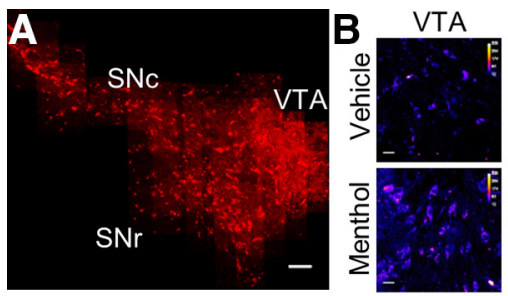

C

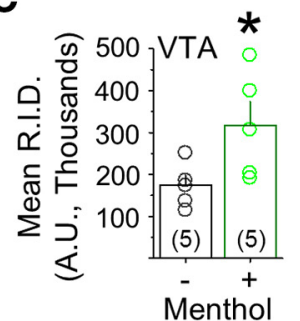

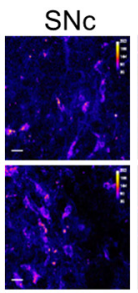
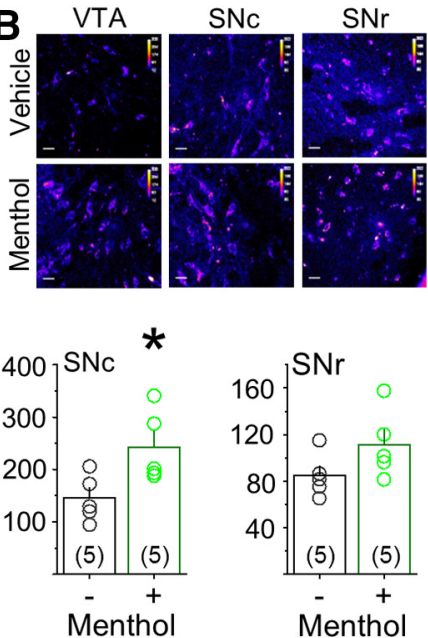

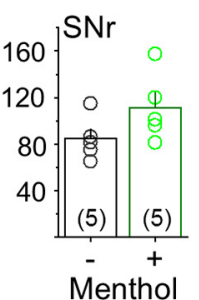

Menthol
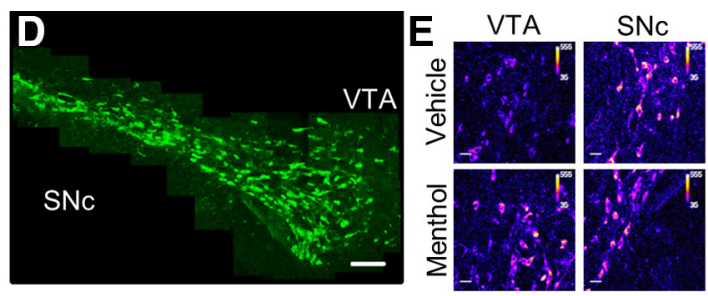

F

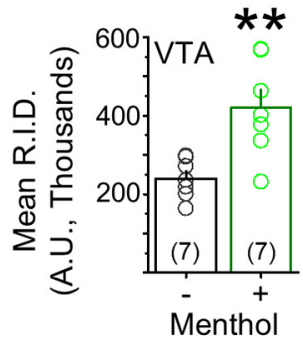

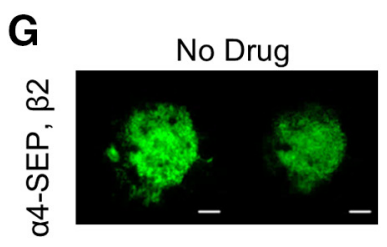

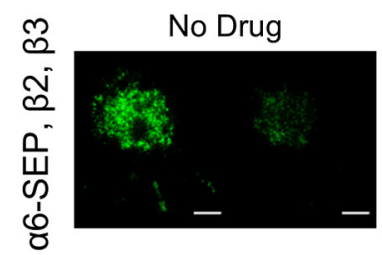

$500 \mathrm{nM}$ Menthol

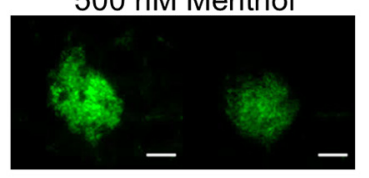

500 nM Menthol

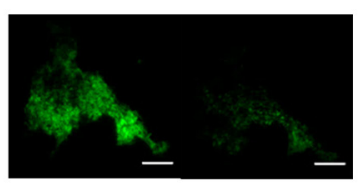

H

$$
\alpha 4-S E P, \beta 2
$$

a6-SEP, $\beta 2, \beta 3$

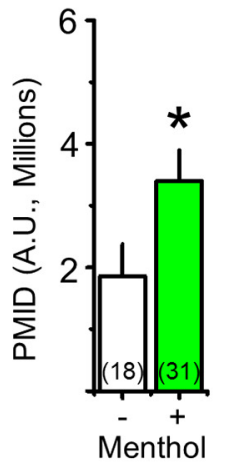

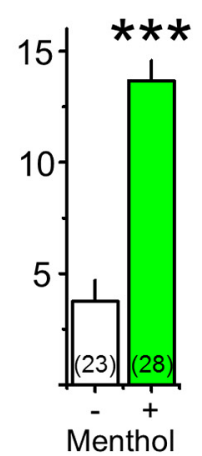

1

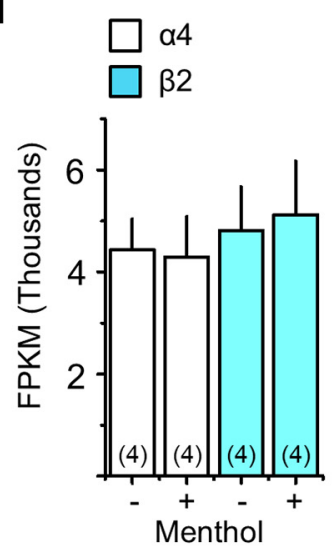

Figure 1. Chronic menthol alone upregulates $\alpha 4^{*}$ and $\alpha 6^{*} \mathrm{nAChRs}$ in vivo. A, Montage of $60 \times$ images from a vehicle-treated $\alpha 4$-mCherry mouse. Scale bar, $100 \mu \mathrm{m}$. $\boldsymbol{B}, 60 \times$ images of $\alpha 4$-mCherry direct fluorescence in the VTA, SNc, and SNr of mice treated with vehicle or menthol ( $2 \mathrm{mg} / \mathrm{kg} / \mathrm{h}, 10 \mathrm{~d})$. Scale bars, $10 \mu \mathrm{m}$. D, Montage of $60 \times$ images from a vehicle-treated $\alpha 6$-GFP mouse. Scale bar, $100 \mu \mathrm{m} . \boldsymbol{E}, 60 \times$ images of $\alpha 6$-GFP direct fluorescence in the VTA and SNc of mice treated with vehicle or menthol. Scale bars, $10 \mu \mathrm{m} . \boldsymbol{B}, \boldsymbol{E}$, Display lookup table "fire" was used in ImageJ. C, $F$, Quantification of $\alpha 4$-mCherry and $\alpha 6$-GFP intensities; transparent circles are mean intensities of individual mice. G, Representative TIRFM images of Neuro-2a cells transfected with $\alpha 4$-SEP and $\beta 2 \mathrm{nAChR}$ subunits or with $\alpha 6$-SEP, $\beta 2$, and $\beta 3 \mathrm{nAChR}$ subunits. Menthol ( $500 \mathrm{~nm}$ ) was added $24 \mathrm{~h}$ before imaging. Scale bars, $10 \mu \mathrm{m}$. In each panel, the left image is at pH 7.4 and the right image is the same cell at pH 5.4. H, PMID was quantified for SEP nAChRs. I, RNA transcript levels of $\alpha 4$ and $\beta 2 \mathrm{nAChR}$ subunits in Neuro-2a cells, detected by RNA sequencing, are unaffected by $500 \mathrm{~nm}$ menthol treatment ( $24 \mathrm{~h}$ ). For all panels, data are mean $\pm \mathrm{SEM} ;{ }^{*} p<0.05 ;{ }^{* *} p<0.01 ;{ }^{* * *} p<0.005$ (unpaired $t$ test). For all panels, number in parenthesis indicates $n$ value.

used where one compartment was black with a stainless steel grid floor and the other was white with a stainless steel mesh floor (Med Associates). The floor of the middle compartment was lined with smooth polyvinyl chloride to make it a neutral zone. Lighting was equilibrated so that there was minimal bias for any of the three chambers. The test consisted of three stages over a $10 \mathrm{~d}$ period (Tapper et al., 2004). Each conditioning period was $20 \mathrm{~min}$. The interval between drug injections and conditioning was $<1$ min as mice were injected and placed directly in the conditioning chamber for their 20 min training period. In the first stage, a mouse was placed in the central compartment and allowed free access to all chambers for $20 \mathrm{~min}$. During stage 2, drug injections were given in the black (saline) or white (nicotine, dissolved in saline) chambers. The mice received intraperitoneal drug injections in the drug-associated conditioning chamber on days $2,4,6$, and 8 , and received intraperitoneal saline injections in the saline-associated chamber on days 3, 5, 7, and 9. Drugnaive mice that exhibited a severe bias toward one of the two conditioning chambers (defined as $>65 \%$ time spent in one chamber) during stage 1 were excluded from the study. Following exclusions, no initial bias was observed in mice (see Fig. 3). Adult male and female C57BL/6 mice (3-6 months old) were used in CPP assays. In total, 14 males and 17 females were used (menthol osmotic minipump group, $0.5 \mathrm{mg} / \mathrm{kg}$ nicotine injection: four males, six females; vehicle osmotic mini-pump group, 0.5 $\mathrm{mg} / \mathrm{kg}$ nicotine injection: four males, four females; saline only group: six males, seven females). No sex differences were observed.

Spectral confocal imaging. Imaging mouse brain slices and cultured Neuro-2a cells containing fluorescent $n A C h R s$ followed procedures and instrumentation previously reported (Srinivasan et al., 2012; Henderson et al., 2014). An Eclipse C1si laser-scanning confocal microscope equipped with a $60 \times 1.2$ numerical aperture VC Plan Apo water objective and 32 photomultiplier tubes was used for confocal imaging. Before an imaging session using cultured Neuro-2a cells, cell culture medium was replaced with phenol red-free $\mathrm{CO}_{2}$-independent Leibovitz (L-15) medium (Invitrogen). eGFP and mCherry were excited at 488 and 561 $\mathrm{nm}$ respectively. eGFP and mCherry fluorescence were obtained. eGFP and mCherry fluorescence emission spectra were captured and images were unmixed using standard spectra acquired from cells expressing eGFP or mCherry only.

For in vivo nAChR upregulation assays, male and female $\alpha 6$-GFP and $\alpha 4$-mCherry mice ( $\sim 3$ months old) were used. No sex differences were observed.

Donor recovery after acceptor photobleaching. We examined Förster resonance energy transfer (FRET) between nAChR subunits using the acceptor photobleaching method (Nashmi et al., 2003; Drenan et al., 2008a). FRET was detected by recording GFP dequenching during incre- 

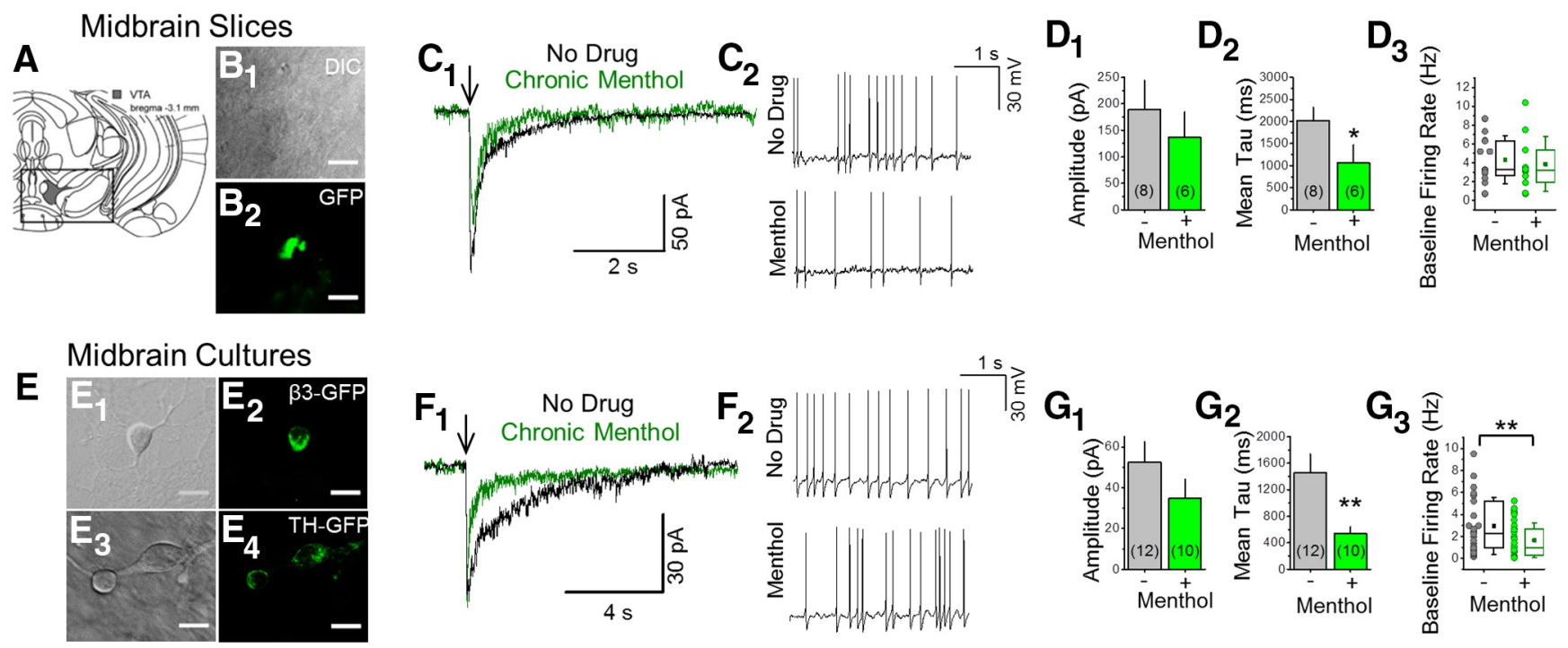
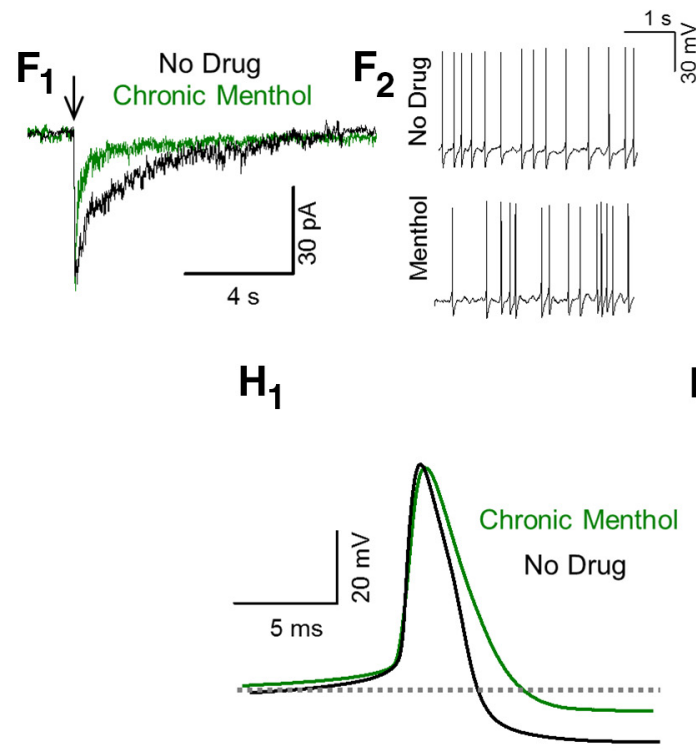
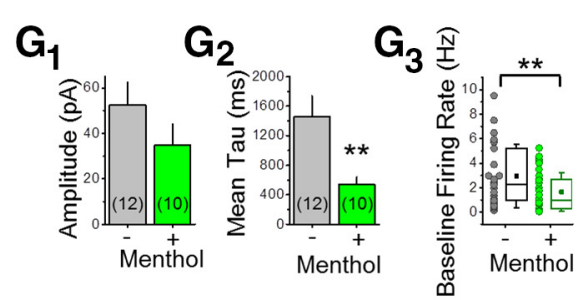

$\mathrm{H}_{2}$

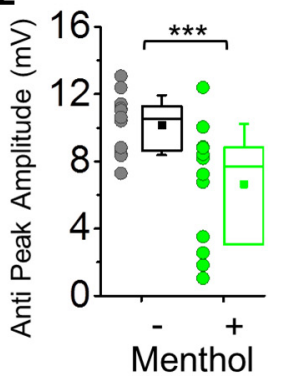

$\mathrm{H}_{3}$

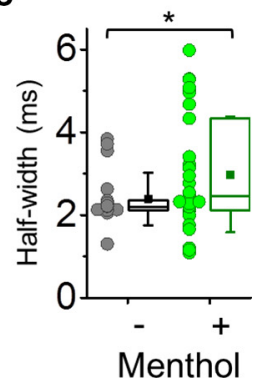

Figure 2. In midbrain DA neurons, chronic menthol does not significantly alter ACh-induced response amplitudes but accelerates their decay and decreases the baseline firing rate. $\boldsymbol{A}-\boldsymbol{D}$, Midbrain slices; VTA DA neurons, bregma $\sim-3.1 \mathrm{~mm} . \boldsymbol{B}_{1}, \boldsymbol{B}_{2}$, Fluorescent neurons in slices from $\alpha 6$-GFP mice. $\boldsymbol{C}_{1}$, Currents induced by ACh puffs. $\boldsymbol{C}_{2}$, Baseline current-clamp traces for no drug-treated and for menthol-treated mice. $\boldsymbol{E}-\boldsymbol{H}$, Midbrain cultures; putative DA neurons. $\boldsymbol{E}_{1}-\boldsymbol{E}_{4}$, Fluorescent neurons from $\beta 3$-GFP or TH-GFP mice. $\boldsymbol{F}_{1}$, Currents induced by ACh puffs. $\boldsymbol{F}_{2}$, Baseline current-clamp traces for no drug-treated and for chronic menthol-treated neurons. $D_{1}, D_{2}, G_{1}, G_{2}$, Summary of ACh response amplitude and decay time constant. $\boldsymbol{D}_{3}$, Histograms for DA neuron firing frequency for vehicle-treated and menthol-treated mouse brain slices ( $n=16$ and 11 for vehicle treated and menthol treated, respectively). $\boldsymbol{G}_{3}$, Histograms for DA neuron firing frequency for no drug-treated and menthol-treated cultured neurons ( $n=23$ and 31 for no drug treated and menthol treated, respectively). $\boldsymbol{E}-\boldsymbol{H}$, Chronic menthol treatment with cultured midbrain DA neurons was $500 \mathrm{~nm}, 7-10$ d. $\boldsymbol{H}$, Chronic menthol alters action potential properties of midbrain DA neurons. $\boldsymbol{H}_{1}$, Mean action potential spike waveform for a no drug-treated and menthol-treated midbrain DA neuron. $\boldsymbol{H}_{2}, \boldsymbol{H}_{\mathbf{3}}$, Quantification of antipeak amplitude and action potential half-width. $\boldsymbol{H}_{2}, n=12$ for both no drug-treated and menthol-treated cultured DA neurons. $\boldsymbol{H}_{3}, n=19$ and 26 for no drug-treated and menthol-treated cultured DA neurons, respectively. In all cases $\left(\boldsymbol{C}_{1}, \boldsymbol{F}_{1}\right)$, arrows indicate $100 \mathrm{~ms}$ puff of $300 \mu \mathrm{m} \mathrm{ACh.} \boldsymbol{D}_{1}, \boldsymbol{D}_{2}, \boldsymbol{G}_{1}, \boldsymbol{G}_{2}$, For all bar graphs, number in parenthesis indicates $n$ value. Data are mean \pm SEM; ${ }^{*} p<0.05 ;{ }^{* *} p<0.005$ (unpaired $t$ test).

mental photodestruction of mCherry. Images were acquired of mCherry bleaching at eight time points, at 10 s intervals, and at a laser excitation of $561 \mathrm{~nm}$. The bleaching protocol was optimized to achieve $\sim 80 \%$ photodestruction of mCherry while still recording increases in GFP emission at each time point. Spectral images were unmixed into their GFP and mCherry components. GFP and mCherry components were saved in Microsoft Excel format and fluorescence intensities were normalized to the prebleach time point $(100 \%)$. FRET efficiency $(E)$ was calculated as $E=1-\left(I_{\mathrm{DA}} / I_{\mathrm{D}}\right)$, where $I_{\mathrm{DA}}$ represents the normalized fluorescence intensity of GFP (100\%) in the presence of both donor (GFP) and acceptor (mCherry), and $I_{\mathrm{D}}$ represents the normalized fluorescence intensity of GFP in the presence of donor only (complete photodestruction of mCherry). The $I_{\mathrm{D}}$ value was extrapolated from a scatter plot of the fractional increase of GFP versus the fractional decrease of mCherry. Data are reported as mean \pm SEM. In figures representing FRET assays, only a single imaging session is represented; however, each result has been repeated in $\geq 3$ sessions on separate days with similar or identical results.

Brain slice preparation (electrophysiology). Recordings were performed using brain slices prepared from 7-11-week-old C57BL/6 [wild type (WT)] mice or $\alpha 6$-GFP nAChR mice, using the protocol described with some modifications (Ye et al., 2006; Xiao et al., 2009). Male and female mice were used; but no sex differences were observed. Mice were killed with $\mathrm{CO}_{2}$, and were subject to cardiac perfusion with ice-cold modified glycerol-based artificial cerebral spinal fluid (GACSF) saturated with 95\% $\mathrm{O}_{2} / 5 \% \mathrm{CO}_{2}$ (carbogen) containing (mM) the following: 250 glycerol, $2.5 \mathrm{KCl}, 1.2 \mathrm{NaH}_{2} \mathrm{PO}_{4}, 1.2 \mathrm{MgCl}_{2}, 2.4 \mathrm{CaCl}_{2}, 26 \mathrm{NaHCO}_{3}$ and 11 glucose. The brain was subsequently removed and sliced with a microslicer (DTK-1000, Ted Pella), while immersed in GACSF. Brain slices were allowed to recover at $32^{\circ} \mathrm{C}$ in a holding chamber filled with carbogenated ACSF containing (mM) the following: $125 \mathrm{NaCl}, 2.5 \mathrm{KCl}, 1.2$ $\mathrm{NaH}_{2} \mathrm{PO}_{4}, 1.2 \mathrm{MgCl}_{2}, 2.4 \mathrm{CaCl}_{2}, 26 \mathrm{NaHCO}_{3}$, and 11 glucose. One hour later, the holding chamber with slices was placed at room temperature. One of the slices was transferred into the recording chamber and superfused $(1.5-2.0 \mathrm{ml} / \mathrm{min})$ with carbogen-saturated ACSF at $32 \pm 0.5^{\circ} \mathrm{C}$.

Patch-clamp electrophysiology. Neurons and Neuro-2a cells were visualized with an upright microscope (BX50WI, Olympus) and nearinfrared or blue illumination (the latter for visualizing fluorescent proteins). Whole-cell patch-clamp techniques were used to record electrophysiological signals with a MultiClamp 700B amplifier (Molecular Devices), Digidata 1322 analog-to-digital converters (Molecular Devices), and pClamp 9.2 software (Molecular Devices). Data were sampled at $10 \mathrm{kHz}$ and filtered at $2 \mathrm{kHz}$. A patch electrode had a resistance of 4-6 $\mathrm{M} \Omega$ when filled with intracellular solutions. Those solutions were as follows: solution 1 (in $\mathrm{mM}$, for most experiments): $135 \mathrm{~K}$-gluconate, 5 $\mathrm{KCl}, 5 \mathrm{EGTA}, 0.5 \mathrm{CaCl}_{2}$, 10 HEPES, $2 \mathrm{Mg}$-ATP, and $0.1 \mathrm{GTP}$; solution 2 (in $\mathrm{mm}$, for particular experiments as stated): $70 \mathrm{~K}$-gluconate, $65 \mathrm{KCl}, 5$ 
EGTA, $0.5 \mathrm{CaCl}_{2}, 10$ HEPES, $2 \mathrm{Mg}$-ATP, $0.1 \mathrm{GTP}$, and $2 \mathrm{QX}-314$. The $\mathrm{pH}$ of these solutions was adjusted to 7.2 with Tris-base, and their osmolarity was adjusted to $300 \mathrm{mOsm}$ with sucrose. The junction potential between patch pipette and bath solutions was nulled just before gigaseal formation. The bath was continually perfused with ACSF. All recordings were done at a temperature of $32 \pm 1^{\circ} \mathrm{C}$.

For cultured cells, 50,000 Neuro-2a cells were plated onto sterilized 12-mm-diameter glass coverslips (Deckgläser), placed in $35 \mathrm{~mm}$ culture dishes, and cultured in a humidified incubator $\left(37^{\circ} \mathrm{C} ; 95 \%\right.$ air, $\left.5 \% \mathrm{CO}_{2}\right)$. Cells were transfected as described below.

Acetylcholine (ACh) was dissolved in extracellular solution containing (in mM) the following: $140 \mathrm{NaCl}, 5 \mathrm{KCl}, 2 \mathrm{CaCl}_{2}, 1 \mathrm{MgCl}_{2}, 10$ HEPES, and 10 glucose (320 mOsm, $\mathrm{pH}$ set to 7.3 with Tris-base). This solution with dissolved ACh was puffed ( 0.1 or $0.3 \mathrm{~s} ; 20 \mathrm{psi}$ ) onto voltage-clamped cells or neurons (holding potential, $-65 \mathrm{mV}$ ). To avoid receptor desensitization by repetitive ACh application, we applied ACh at $\sim 3$ min intervals and continually perfused the recording chamber with extracellular solution.

For concentration-response curves (see Fig. 5), drug applications were performed using an Octaflow II perfusion system $(0.5 \mathrm{~s}, 8$ psi; ALA Scientific). Curve fitting was completed with KaleidaGraph 4.5 and plotted in Origin 10.

Total internal reflection fluorescence microscopy. Cultured Neuro-2a cells were imaged live at $37^{\circ} \mathrm{C}$ in a stage-mounted culture dish incubator (Warner Instruments) using methods and instrumentation reported previously (Richards et al., 2011; Henderson et al., 2014). Total internal reflection fluorescence microscopy (TIRFM) enables the visualization of fluorescently labeled intracellular molecules within $\sim 250 \mathrm{~nm}$ of the cellcoverslip interface. Just before imaging, growth medium was exchanged for extracellular solution ( $150 \mathrm{~mm} \mathrm{NaCl}, 4 \mathrm{~mm} \mathrm{KCl,} 10 \mathrm{~mm}$ HEPES, $2 \mathrm{~mm}$ $\mathrm{MgCl}_{2}, 2 \mathrm{mM} \mathrm{CaCl}_{2}$, and $10 \mathrm{~mm}$ glucose) adjusted to the appropriate $\mathrm{pH}$ (5.4 or 7.4). Superecliptic pHluorin (SEP) was excited at $488 \mathrm{~nm}$ with an air-cooled argon laser (IMA101040ALS, Melles Griot). We acidified the imaging dish by perfusing the bath, normally at $\mathrm{pH} 7.4$, with an otherwise identical solution adjusted to $\mathrm{pH}$ 5.4. The plasma membrane integrated density (PMID) was determined by taking an initial TIRFM image of each cell at $\mathrm{pH} 7.4$ followed by acidification of the solution and a subsequent low-pH image ( $\mathrm{pH}$ 5.4). Low-pH images were used to demarcate endoplasmic reticulum-localized nAChRs that were subtracted from the total footprint to determine the PMID of nAChRs.

Neuro-2a cell culture and transient transfections. Neuro-2a cells were cultured using standard techniques (Srinivasan et al., 2011). Cells were plated by adding 90,000 cells to poly-D-lysine-coated $35 \mathrm{~mm}$ glassbottom imaging dishes (MatTek) and cultured in a humidified incubator $\left(37^{\circ} \mathrm{C}\right.$; $95 \%$ air, $\left.5 \% \mathrm{CO}_{2}\right)$. Cells were transfected with $500 \mathrm{ng}$ of each $\mathrm{nAChR}$ subunit cDNA. In assays using two fluorescent variants of the same nAChR subunit ( $\alpha 4$-GFP and $\alpha 4$-mCherry; see Fig. $5 B_{1}, B_{2}$ ), $250 \mathrm{ng}$ of each subunit were used so that the total amount per subunit was 500 ng. Plasmids were mixed with $250 \mu \mathrm{l}$ of Opti-MEM. Lipofectamine 2000 was separately added to $250 \mu \mathrm{l}$ of Opti-MEM. After $5 \mathrm{~min}$ at $24^{\circ} \mathrm{C}$, DNA and lipofectamine solutions were mixed together and incubated for 25 $\min$ at $24^{\circ} \mathrm{C}$. The solutions were then added to preplated Neuro-2a cells and incubated for $24 \mathrm{~h}$. After $24 \mathrm{~h}$, the Opti-MEM was removed and replaced with growth medium. Fifty nanomolars filter-sterilized nicotine was added after replacing the Opti-MEM with standard culture medium ( $\alpha 6 \beta 2 \beta 3$ nAChRs). For $\alpha 4 \beta 2$ nAChRs, $100 \mathrm{~nm}$ nicotine was present for $48 \mathrm{~h}$ (nicotine was added at the time of transfection and then replenished when the media was changed). CI-976 was added $(20 \mu \mathrm{M})$ with nicotine $24 \mathrm{~h}$ before imaging. Cells were imaged $48 \mathrm{~h}$ after transfection.

We used different concentrations of nicotine (50 or $100 \mathrm{~nm}$ ) for $\alpha 6 \beta 2 \beta 3$ and $\alpha 4 \beta 2$ nAChRs because we have found that robust and consistent upregulation of nAChR number in TIRFM assays occurs at these concentrations using Neuro-2a cells (Richards et al., 2011; Henderson et al., 2014).

Cultured midbrain neurons. To culture primary midbrain neurons from mouse embryos, ventral midbrain tissue from embryonic day 14 embryos was dissected out and cultured using previously published procedures (Srinivasan et al., 2016). Following digestion with papain (15 min at $37^{\circ} \mathrm{C}$ ), cells were separated by DNase treatment and trituration,
Table 1. Comparison of electrophysiological characteristics among cultured midbrain neurons derived from WT, $\beta 3$-eGFP, and TH-eGFP mice

\begin{tabular}{lll}
\hline & Peak current amplitude & Firing frequency \\
\hline WT & $54.4 \pm 12.3 \mathrm{pA}$ & $3.9 \pm 1.9 \mathrm{~Hz}$ \\
$\beta 3$-eGFP & $46.9 \pm 8.6 \mathrm{pA}$ & $3.2 \pm 0.7 \mathrm{~Hz}$ \\
TH-eGFP & $53.8 \pm 17.7 \mathrm{pA}$ & $4.1 \pm 0.8 \mathrm{~Hz}$ \\
\hline
\end{tabular}

Values are represented as mean $\pm \mathrm{SEM} ; n=9-13$ neurons for each genotype.

and plated at a density of 100,000 cells per dish in poly-L-ornithine and laminin-coated imaging dishes containing Neurobasal medium supplemented with B27, Glutamax, 1\% Hyclone equine serum, and $100 \mu \mathrm{M}$ ascorbate. Either control medium or $200 \mathrm{~nm}$ nicotine was added to the culture for 2 weeks from day 7 to day 21 . Media were changed every $3 \mathrm{~d}$. Recordings (peak currents, hyperpolarization-activated current, action potential duration, and baseline firing rates) did not differ among putative DA neurons from WT, $\beta 3$-eGFP, or TH-eGFP cultures (See Table 1).

Single-cell harvesting and RNA extraction using cultured midbrain DA neurons. Cells were harvested on day 21 in culture, following previously reported procedures (Henley et al., 2013; Srinivasan et al., 2016). Glass capillary tubing (Kimax-51; 1.5-1.8 mm outer diameter) was cleaned by sonication in ethanol and then baked overnight at $200^{\circ} \mathrm{C}$ to inactivate RNase. Large-bore glass micropipettes (10-30 $\mu \mathrm{m}$ tip diameter) were pulled from the tubing using a Sutter P-50 microelectrode puller. Before harvesting, we removed the media from the culture dishes, rinsed them with $2 \mathrm{ml}$ of Dulbecco's PBS, and replaced $1 \mathrm{ml}$ of Dulbecco's PBS remaining in the dish for harvesting. Individual cultured neurons were identified using a microscope equipped with a $40 \times$ phase objective. The pipette was positioned over the cell soma using a motorized micromanipulator (Sutter Instrument); the cell was aspirated into the glass micropipette using gentle suction. The micropipette containing the cell was immediately removed from the bathing solution, placed inside a plastic, RNase-free microcentrifuge tube containing $1.5 \mu \mathrm{l}$ of RNase-free PBS and $0.5 \mu \mathrm{l}$ of an RNase inhibitor solution, and its tip was broken against the side of the tube near the bottom. We applied outward pressure to the broken micropipette using a large-gauge syringe needle to expel the remaining fluid at the tip of the micropipette into the tube. The tube was then centrifuged briefly using a desktop centrifuge and then frozen on dry ice. Typically, 16 cells were harvested per dish over a $1 \mathrm{~h}$ period at ambient temperature. The resultant mRNAs were reverse transcribed and amplified to construct single-neuron high-yield cDNA sequencing libraries.

Laser-capture microdissection of adult mouse SNc neurons. As previously described in detail (Henley et al., 2013), whole brains from 4 -month-old male mice were collected (postmortem interval of $<5$ $\min$ ), fresh frozen over dry ice, and stored at $-80^{\circ} \mathrm{C}$. Midbrain cryostat sections $(20 \mathrm{~mm})$ were mounted on UV-treated Zeiss membrane slides (1.0 polyethylene naphthalate nuclease-free), air dried for $5 \mathrm{~min}$, and stained with cresyl violet for $1 \mathrm{~min}$. The sections were rinsed, dried, and then visualized under bright-field illumination at $400 \times$ magnification on a Zeiss Palm laser capture microdissection microscope. Twenty putative $\mathrm{DA}^{+}$cell bodies from the $\mathrm{SNc}$ were dissected using multiple low laser energy pulses, and were catapulted into Zeiss $200 \mu \mathrm{l}$ adhesive caps. Cell lysis solution (Illumina) containing 30 SMART reverse transcription primers and quantitation controls ("spikes") were then added into the pool of cells before freezing.

Harvesting of RNA from Neuro-2a cells. We used a mirVana miRNA Isolation Kit (Life Technologies) to prepare RNA samples. Cells were processed fresh (i.e., not frozen). Media in dishes containing neuro-2a cells transiently transfected with $\alpha 4$-SEP and $\beta 2$ nAChR subunits were aspirated, rinsed in $1 \mathrm{ml}$ PBS, and then the PBS wash was aspirated. Neuro-2a cells were lysed directly in the culture plate using $600 \mu \mathrm{l}$ of lysis/binding solution. The lysate was collected with a rubber spatula and pipetted into a tube where it was pipetted to obtain a homogenous lysate. miRNA homogenate additive (one-tenth volume of lysate) was added to the tube containing the lysate, vortexed, and left on ice for $10 \mathrm{~min}$, and then acid-phenol-chloroform was added at a volume equal to lysate. Lysate was vortexed for $60 \mathrm{~s}$ and then centrifuged for $5 \mathrm{~min}$ at $10,000 \times g$ at room temperature. The aqueous phase was then removed and trans- 
ferred to a fresh tube. One hundred percent ethanol was added (1.25 times the volume of lysate) to the aqueous phase. The ethanol/lysate mixture was pipetted onto a filter cartridge and centrifuged for $15 \mathrm{~s}$, repeatedly, until all of the ethanol/lysate mixture passed through the filter. Seven hundred microliters of miRNA Wash Solution 1 was added to the filter and the filter was centrifuged for $10 \mathrm{~s}$. Five hundred microliters of Wash Solution 2/3 was added to the filter and then centrifuged for $10 \mathrm{~s}$ (twice). One hundred microliters of preheated $\left(95^{\circ} \mathrm{C}\right)$ elution solution was used to recover the RNA. The eluate, containing the RNA, was stored at $-80^{\circ} \mathrm{C}$ with $2.5 \mu \mathrm{l}$ RNase inhibitor. A Turbo DNA-free Kit (Life Technologies) was used to remove contaminating DNA from RNA preparations.

RNA sequencing. We prepared amplified cDNA from RNA using Clontech's SMARTerTM Ultra Low RNA system for Illumina Sequencing (Clontech). We used Clontech's Advantage 2 PCR system for amplification of cDNA templates by long-distance PCR. Illumina's Nextera DNA Sample Preparation kit with Tn5-mediated tagmentation technology (Epicenter) was used as an in vitro transposition method to simultaneously fragment and tag the cDNA libraries with Illumina-compatible sequencing primers. After quality control measures of yield and fragment length distribution were taken using the Qubit fluorometer (Invitrogen) and the Agilent Bioanalyzer, $100 \mathrm{bp}$ sequencing reads were generated on the Illumina HiSeq instrument. Each sequencing library generated $>20$ million unique mapping reads.

RNA sequencing computational analysis. One hundred base pair sequence tags were mapped to the mouse genome using TopHat 1.3.2. We quantified transcript abundance [fragments per kilobase per million mapped reads (FPKM)] using Cufflinks. We annotated the transcripts with genome annotations provided by Ensembl. We conducted pairwise comparisons and calculated statistical values using Cuffdiff, part of the Cufflinks suite, to identify differentially expressed genes. We assessed ontology with DAVID (Database for Annotation, Visualization and Integrated Discovery; Huang da et al., 2009). Cuffdiff data with FPKM $>1$, a corrected $p$ value of $<0.05$ and a fold difference of $>1.5$ were given as input to Ingenuity Pathway Analysis (Qiagen) for pathway analysis.

\section{Results}

Menthol alone upregulates $\alpha 4^{*}$ and $\alpha 6^{*} n A C h R$ subunits in vivo How does menthol enhance nicotine-induced upregulation? One possibility is that menthol upregulates nAChRs, independent of nicotine. To test this idea, we used mice containing mCherrylabeled $\alpha 4^{*} \mathrm{nAChRs}$ or GFP-labeled $\alpha 6^{*} \mathrm{nAChRs}$ and a "chronic" menthol concentration of $2 \mathrm{mg} / \mathrm{kg} / \mathrm{h}$ for $10 \mathrm{~d}$. Previous studies show that these fluorescent nAChR subunits assemble appropriately with nonlabeled subunits, traffic properly, and function in a manner comparable to WT nAChRs (Nashmi et al., 2007; Mackey et al., 2012; Henderson et al., 2014; Shih et al., 2014). In midbrain, both DA neurons and GABAergic neurons express $\alpha 4^{\star}$ nAChRs (Nashmi et al., 2007; Mackey et al., 2012). In GABAergic neurons of the SNr, the fluorescence intensity of $\alpha 4$ mCherry nAChRs did not change following menthol treatment (Fig. $1 A-C$ ). In contrast, the fluorescence intensities of $\alpha 4$ mCherry $^{\star}$ nAChRs were 58.5 and $54.2 \%$ greater in VTA and SNc neurons, respectively, when compared with those of vehicletreated mice (Fig. $1 A-C ; p<0.05$ ).

In midbrain, $>90 \%$ of TH-positive neurons express $\alpha 6^{*}$ and $\beta 3^{*}$ nAChRs; GABAergic neurons do not (Drenan et al., 2008b; Mackey et al., 2012; Srinivasan et al., 2016). The fluorescence intensities of $\alpha 6$-GFP neurons in the VTA and SNc were $75.0 \%$ and $46.5 \%$ greater in menthol-treated mice when compared with vehicle-treated mice (Fig. $1 D-F ; p<0.05$ ). These data show that menthol alone upregulates $\alpha 4^{*}$ and $\alpha 6^{*}$ nAChR subunits in midbrain DA neurons.

Given that no $\alpha 4^{\star}$ upregulation was noted in GABAergic neurons, menthol seems to exert some cell specificity. We have found that nicotine also exerts a cell-specific effect as it up- regulates $\alpha 4^{*}$ nAChRs in somata of GABA neurons but does not upregulate $\alpha 4^{\star} \mathrm{nAChRs}$ in somata of DA neurons of the VTA or SNc (Nashmi et al., 2007). Despite observing cellspecific upregulation, we see that menthol and nicotine exhibit different cell-specific targets: menthol upregulates $\alpha 4^{*}$ nAChRs in somata of the VTA and SNc (Fig. 1) but nicotine upregulates $\alpha 4^{*}$ nAChRs only in somata of GABA neurons (Nashmi et al., 2007).

\section{Menthol upregulates $n A C h R$ s on the PM}

Using mice containing fluorescent $\mathrm{nAChRs}$ is an appropriate method to study $\mathrm{nAChR}$ upregulation in vivo, but is not readily amenable to study changes in nAChR number on the PM. To study nAChR subunit upregulation on the PM, we used nAChRs tagged to SEP, a pH-sensitive GFP analog, and TIRFM (Fig. 1G,H; Richards et al., 2011; Henderson et al., 2014; Nichols et al., 2014). We used transient heterologous expression in the neuronlike Neuro-2a cell line. As previously documented (Moss et al., 2009), Neuro-2a cells express transfected proteins at lower levels than various HEK293-derived cell lines. This allows one to control nAChR stoichiometry by varying the cDNA levels of each plasmid, and various trafficking processes remain unsaturated, so that individual steps can be studied in early and late exocytotic pathways (Son et al., 2009; Srinivasan et al., 2011, 2012; Xiao et al., 2011; Henderson et al., 2014). Neuro-2a cells also robustly express $\alpha 6^{*}$ nAChRs (Henderson et al., 2014).

Cells expressing $\alpha 4$-SEP $\beta 2 \mathrm{nAChRs}$ were treated $(24 \mathrm{~h})$ with no drug or with $500 \mathrm{~nm}$ menthol (Fig. $1 G, H) . \alpha 4$-SEP $\beta 2$ nAChRs treated with menthol exhibited a significant $(p<0.05)$ twofold increase in PMID (Fig. $1 H$ ). Cells transfected with $\alpha 6$-SEP, $\beta 2$, and $\beta 3 \mathrm{nAChR}$ subunits, treated with menthol, exhibited a threefold increase in PMID (Fig. $1 H$ ), which is similar to previous observations with $24 \mathrm{~h}$ nicotine treatment (Henderson et al., 2014). We assessed gene expression on $\alpha 4$ and $\beta 2$ nAChR subunits in transfected Neuro-2a cells treated with no drug or with $500 \mathrm{~nm}$ menthol for $24 \mathrm{~h}$ (Fig. 1I). We detected no change in $\alpha 4$ or $\beta 2 \mathrm{nAChR}$ subunit transcripts in menthol-treated versus nodrug-treated Neuro-2a cells. From these data, we conclude that menthol alone robustly upregulates $\alpha 4^{*}$ and $\alpha 6^{*}$ nAChRs on the $\mathrm{PM}$, via post-translational mechanism(s).

\section{Chronic menthol exposure alters native $n A C h R$ function}

In addition to increasing $\mathrm{nAChR}$ number in midbrain neurons, nicotine also alters the function of midbrain neurons of the DA reward pathway (Nashmi et al., 2007; Xiao et al., 2009; Faure et al., 2014). Thus, using electrophysiology, we investigated how long-term menthol treatment affects the function of midbrain VTA neurons (Fig. 2). As mentioned, $\alpha 6^{*}$ nAChRs in the midbrain are selectively expressed in DA neurons of the VTA and SNc (Drenan and Lester, 2012; Mackey et al., 2012). We prepared brain slices from $\alpha 6-\mathrm{GFP}$ mice to facilitate identification of VTA DA neurons (Fig. $2 A, B_{1}, B_{2}$ ). Interestingly, treatment with menthol $(2.0 \mathrm{mg} / \mathrm{kg}, 10 \mathrm{~d}) \mathrm{did}$ not significantly change peak current amplitude (Fig. $2 C_{1}, D_{1}$ ), but did accelerate the decay phase of nAChR currents stimulated by $300 \mu \mathrm{M}$ ACh (100 ms puff; Fig. $\left.2 C_{1}, D_{2}\right)$. This functional modification of nAChRs following chronic menthol treatment was not accompanied by a significant change in baseline firing rates of VTA DA neurons (Fig. $2 C_{2}, D_{3} ; 4.25 \pm 0.61$ and $3.85 \pm 0.88 \mathrm{~Hz}$ for vehicle and menthol-treated mice, respectively).

We also examined effects of long-term, submicromolar menthol ( $500 \mathrm{nM}, 7-10 \mathrm{~d})$ on native nAChRs using cultured midbrain neurons (Fig. $2 E, H$ ). To facilitate the identification of DA neurons, we used primary cultures from $\beta 3$-eGFP knock-in mice 
$A_{1}$

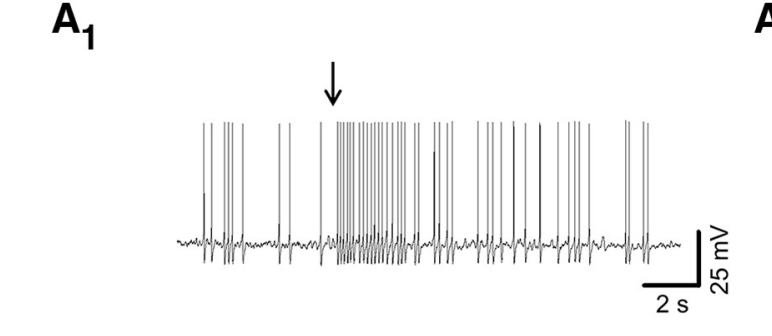

$B_{1}$

No Drug

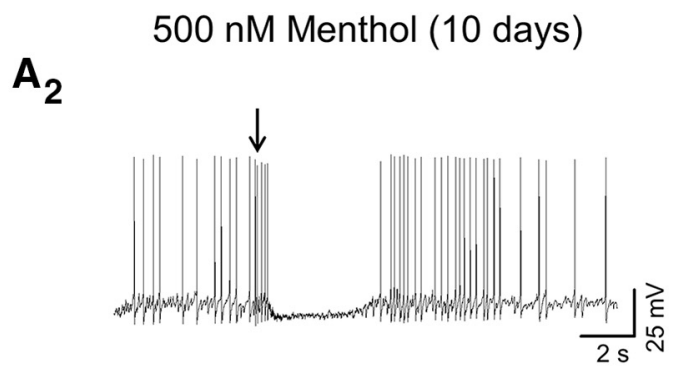

$B_{2}$
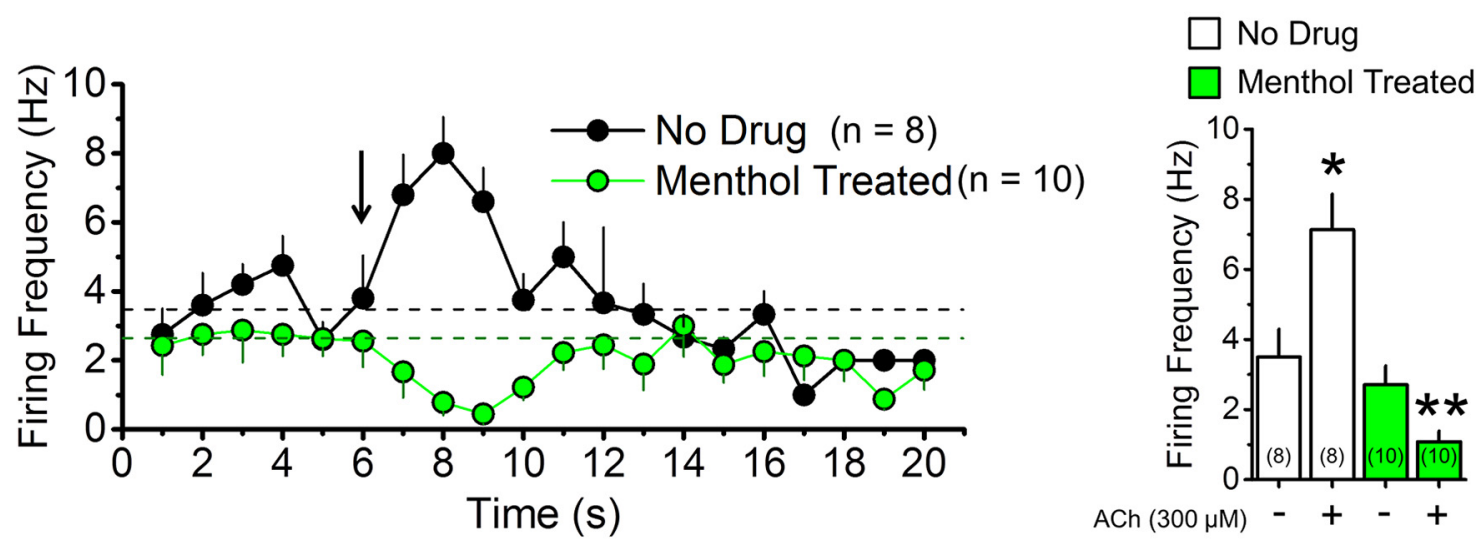

$500 \mathrm{nM}$ Menthol (10 days)

$\mathrm{C}_{1}$

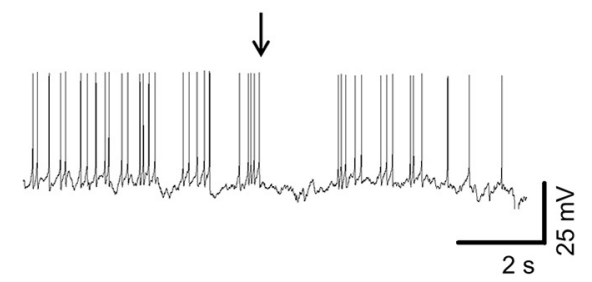

$500 \mathrm{nM}$ Menthol (10 days)

+ sulpiride

$\mathrm{C}_{2}$

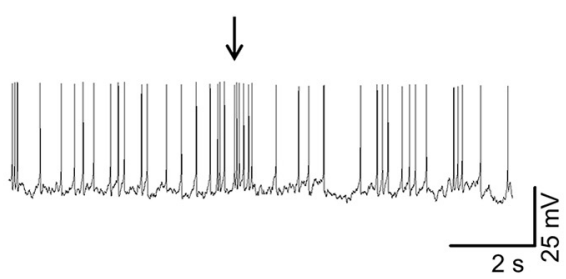

Figure 3. Long-term menthol treatment prevents $n A C h R$-induced acceleration of $D A$ neuron firing frequency. $A$, Current-clamp recordings from cultured midbrain DA neurons treated with no drug $\left(A_{1}\right)$ or treated with $500 \mathrm{~nm}$ menthol over $10 \mathrm{~d}\left(A_{2}\right)$ before and after an ACh puff. $B_{1}$, Time course of firing frequency before and after a $100 \mathrm{~ms}$ ACh puff. Dashed lines are mean firing frequency for no drug-treated and menthol-treated neurons before the $A C h$ puff. $\boldsymbol{B}_{2}$, Quantification of firing frequency in no drug-treated and menthol-treated conditions before and after $A C h$ puff. Mean for pre-ACh $(-)$ and post-ACh $(+)$ puff are the 3 s before and after the ACh puff. Data are mean \pm SEM; ${ }^{*} p<0.05 ;{ }^{* *} p<0.001$ (unpaired $t$ test). In all cases, arrows indicate $100 \mathrm{~ms}$ puff of $300 \mu \mathrm{M}$ ACh. $\boldsymbol{C}$, Current-clamp recordings from cultured midbrain DA neurons treated with $500 \mathrm{~nm}$ menthol (10 d) without sulpiride $\left(\boldsymbol{C}_{\mathbf{1}}\right)$ or with acute exposure to $1 \mu \mathrm{m}$ sulpiride $\left(\boldsymbol{C}_{2}\right)$. In all traces, arrows show a $100 \mathrm{~ms}$ puff of $300 \mu \mathrm{m}$ ACh. Number in parenthesis indicates $n$ value.

(like $\alpha 6^{*}$, selectively expressed on DA neurons of the VTA and SNc; Shih et al., 2014) or from TH-eGFP mice (Fig. $2 E_{1}-E_{4}$; Srinivasan et al., 2016). Recordings (peak currents, hyperpolarizationactivated current, action potential duration, and baseline firing rates) did not differ among putative DA neurons from WT, $\beta 3$ eGFP, or TH-eGFP cultures (Table 1). We chose not to use cultures from $\alpha 6$-GFP embryos because these arise from heterozygote $\times$ WT crosses (Mackey et al., 2012; Srinivasan et al., 2016) and produce fewer fluorescent neurons in culture than the available embryos from homozygote $\times$ homozygote crosses $(\beta 3$ eGFP). We found that the TH-eGFP cultures gave the most robust fluorescent signals and allowed for easiest identification of putative DA neurons. Thus, the majority of electrophysiological data were acquired using cultures from TH-eGFP mice.

In agreement with recordings from mouse brain slices, longterm menthol significantly accelerated $\mathrm{nAChR}$ decay rates elicited by $300 \mu \mathrm{M}$ ACh (100 ms puff; Fig. $2 F_{1}, G_{2}$ ) and did not alter peak current amplitude (Fig. $2 F_{1}, G_{1}$ ). Menthol treatment significantly decreased baseline firing rates of midbrain DA neurons (Fig. $2 F_{2}, G_{3}$ ). Additionally, we observed that menthol treatment increased the half-width of DA neuron action potentials $(p<$ 0.05; Fig. $2 H_{1}-H_{3}$ ). With mouse brain slices and cultured midbrain neurons, we observed no effects of menthol when applied acutely (500 nM; data not shown).

Classical data show that nAChR agonists acutely increase firing of midbrain DA neurons (Brodie, 1991; Liu et al., 2012). Previous data also show that this effect is blunted by chronic nicotine treatment (Nashmi et al., 2007). Since menthol decreases baseline firing (Fig. $2 F_{2}, G_{3}$ ) similar to nicotine (Nashmi et al., 2007; Xiao et al., 2009), we studied whether menthol also alters the agonist-induced transient increase in DA neuron firing frequency. ACh application $(300 \mu \mathrm{M}, 100 \mathrm{~ms})$ transiently increased cultured DA neuron firing frequency (Fig. $3 A_{1}, B_{1}, B_{2}$ ). Following long-term treatment with menthol (500 nM, 7-10 d), 
A

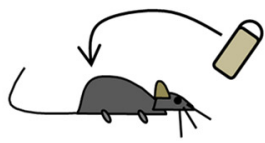

Osmotic mini-pump

Vehicle or Menthol

(day 1 - 20)
Nicotine $(0.5 \mathrm{mg} / \mathrm{kg})$ Alt. Days

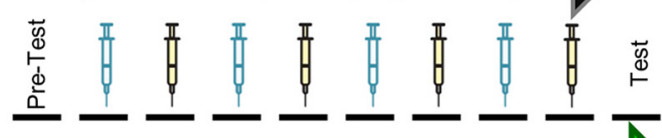

Saline or Menthol $(2.0 \mathrm{mg} / \mathrm{kg} / \mathrm{h})$

Day

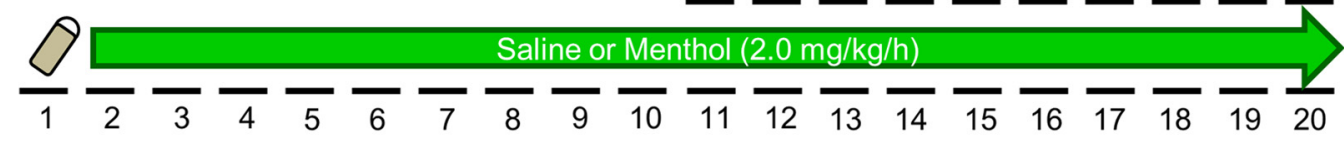

B
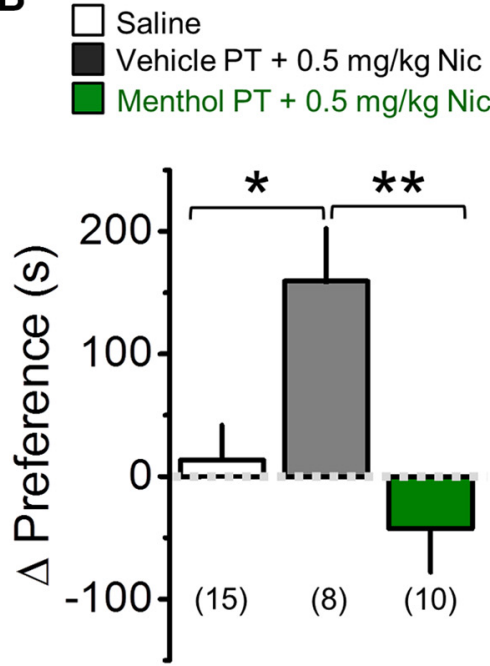

C

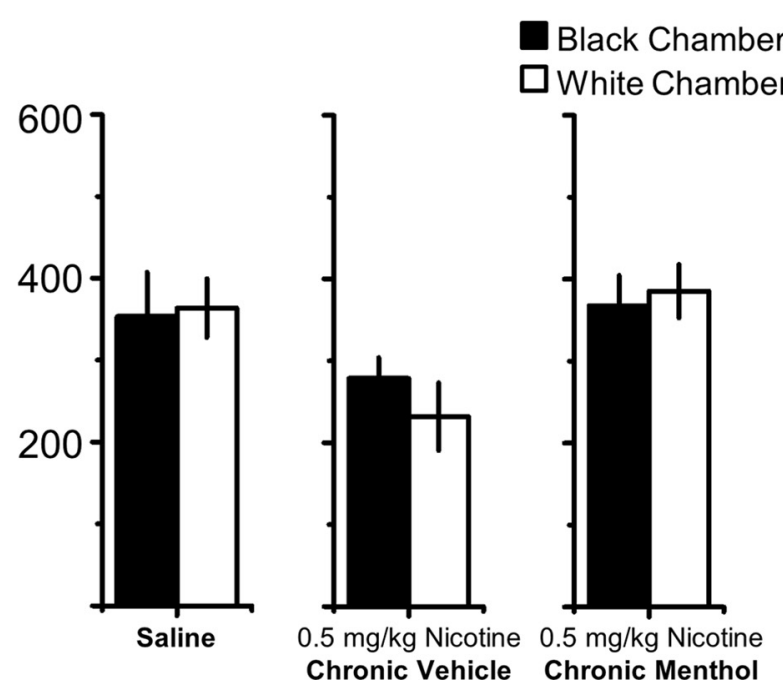

Figure 4. Chronic menthol before nicotine exposure abolishes nicotine reward-related behavior. $A$, Schematic of CPP assay. Mice were implanted with osmotic minipumps for $20 \mathrm{~d}$ to continuously deliver $2 \mathrm{mg} / \mathrm{kg} / \mathrm{h}$ menthol or vehicle $10 \mathrm{~d}$ before and during CPP training. $\boldsymbol{B}$, Saline control mice did not exhibit a change in baseline preference. Mice implanted with osmotic minipumps delivering vehicle exhibited reward-related behavior to $0.5 \mathrm{mg} / \mathrm{kg}$ nicotine, but those receiving menthol exhibited no reward-related behavior to $0.5 \mathrm{mg} / \mathrm{kg}$ nicotine. Data are mean \pm SEM; one-way ANOVA, $F=8.28 ;{ }^{*} p<0.05$, post hoc Tukey's test. Number in parenthesis indicates $n$ value. C, Mice exhibited no significant preference for the white or black chambers during the initial test phase.

cultured DA neurons displayed a transient decrease in firing frequency following ACh application (Fig. $3 A_{2}, B_{1}, B_{2}$ ). Here we see that long-term menthol alone exerts an effect opposite to that of long-term nicotine. Nicotine treatment permits a transient increase in DA neuron firing frequency following $\mathrm{nAChR}$ agonist application (Nashmi et al., 2007). Menthol treatment, in contrast, causes a transient decrease in DA neuron firing frequency following $\mathrm{nAChR}$ agonist application. In $80 \%$ of the recordings, cultured DA neurons were hyperpolarized following an ACh puff (Fig. $3 A_{2}$ ). In previous reports, midbrain DA neurons were similarly hyperpolarized by acute DA application (Ingram et al., 2002). To determine whether the hyperpolarization we observed in menthol-treated DA neurons is mediated through dopamine $\mathrm{D}_{2}$-like receptors [D2Rs, but possibly including $\mathrm{D}_{3}$ receptors (Collo et al., 2013)], we used the D2R antagonist sulpiride. Cultured midbrain DA neurons treated with $500 \mathrm{~nm}$ menthol (7-10 d) were recorded in current-clamp mode (as in Fig. $3 A_{1}, A_{2}, B_{1}, B_{2}$ ) and exposed to ACh $(100 \mathrm{~ms}, 300 \mu \mathrm{M})$. DA neurons were then bath perfused with extracellular solution containing $1 \mu \mathrm{M}$ sulpiride to block D2Rs, and then re-exposed to ACh $(100 \mathrm{~ms}$, $300 \mu \mathrm{M}$; Fig. $\left.3 C_{1}, C_{2}\right)$. DA neurons that were hyperpolarized following an ACh puff (Fig. $3 C_{1}$ ) lacked this response during sulpiride exposure (Fig. $3 C_{2}$ ). This suggests that menthol may also play a role in altering DA neuron excitability via somatic DA release that results from activation of D2Rs or activation of G-protein-activated inward rectifier channels.

Nicotine's ability to reduce DA neuron baseline firing frequency is believed to be one contributing feature of addiction as this may enhance the fraction of DA release during burst firing (Sulzer, 2011). Long-term menthol's ability to reduce baseline firing frequency of midbrain DA neurons may cause an analogous alteration in DA release. However, nAChR activation decreases DA neuron firing frequency transiently following longterm menthol treatment, which is opposite to what happens following acute nAChR activation, which has the classical effect of transiently increasing the firing frequency of DA neurons. Therefore long-term menthol treatment may alter nicotine rewardrelated behavior. To address this, we studied effects of long-term exposure to menthol on nicotine reward-related behavior.

\section{Chronic menthol abolishes nicotine reward-like behavior}

CPP is appropriate for studying nicotine reward-related behavior (Tapper et al., 2004). We tested how long-term (10 d) menthol treatment prior to nicotine exposure alters CPP. Similar to treatment before microscopy and electrophysiology measurements, mice were treated with vehicle or $2.0 \mathrm{mg} / \mathrm{kg} / \mathrm{h}$ menthol for $10 \mathrm{~d}$ using osmotic minipumps; we then began the conventional $10 \mathrm{~d}$ training and testing regimen for CPP (Fig. 4A). On day 11 (after $10 \mathrm{~d}$ of vehicle or menthol exposure), mice were tested for initial preference, and training began on day 12 for CPP assays using nicotine $(0.5 \mathrm{mg} / \mathrm{kg})$. Final testing was conducted on day 20 . During the training and testing for CPP (days 11-20), mice continued to receive vehicle or menthol (Fig. $4 A$ ). Mice receiving saline only exhibited no reward-related behavior (Fig. 4B). Mice treated long-term with vehicle and receiving $0.5 \mathrm{mg} / \mathrm{kg}$ nicotine in the drug-associated chamber during training exhibited a 
change in preference toward the drug-associated chamber (Fig. $4 B)$. In contrast, mice treated long-term with menthol prior to receiving $0.5 \mathrm{mg} / \mathrm{kg}$ nicotine showed a slight change in preference away from the drug-associated chamber (Fig. 4B). Thus, longterm treatment with menthol displayed no measureable nicotine reward-related behavior (Fig. $4 B ; p<0.05$ ). In initial testing, none of the mice showed a severe bias toward the black or white chambers (Fig. 4C).

We observed this menthol-dependent decrease or abolition of nicotine reward-related behavior, despite recent data that simultaneous exposure to menthol and nicotine enhances nicotine reward and reinforcement (Gandhi et al., 2009; Ahijevych and Garrett, 2010; Wang et al., 2014). These contrasting observations point to the fact that menthol may act differently alone than when combined with nicotine. To identify the mechanism of how this may occur, we examined menthol's ability to alter nAChR assembly and stoichiometry.

\section{Menthol alters $\alpha 4 \beta 2$ and $\alpha 6 \beta 2^{*} n A C h R$ assembly and stabilizes lower-sensitivity $n A C h R s$}

Previous studies show that $\alpha 4 \beta 2$ nAChRs assemble in two stoichiometries: the higher-sensitivity and lower-sensitivity forms are $(\alpha 4)_{2}(\beta 2)_{3}$ and $(\alpha 4)_{3}(\beta 2)_{2}$, respectively (Nelson et al., 2003; Kuryatov et al., 2005). Similarly, $\alpha 6 \beta 2^{\star}$ nAChRs assemble in at least two forms, depending on the inclusion of a $\beta 3$ subunit: the $(\alpha 6)_{2}(\beta 2)_{2} \beta 3$ form has a higher agonist sensitivity than the $\alpha 6 \beta 2$ form (the stoichiometry of the latter is unknown; Tumkosit et al., 2006; Xiao et al., 2011; Henderson et al., 2014). Eponymously, these higher-sensitivity and lower-sensitivity stoichiometries are manifested by concentration-response curves (Nelson et al., 2003; Kuryatov et al., 2005). We therefore studied menthol's effect on ACh sensitivity with $\alpha 4 \beta 2$ and $\alpha 6 \beta 2^{*}$ nAChRs.

Neuro-2a cells were transiently transfected with $\alpha 4$-eGFP $\beta 2$ or $\alpha 6$-eGFP $\beta 2 \beta 3 \mathrm{nAChRs}$ and were treated with no drug or with menthol (500 nM, 24 h). As expected (Nelson et al., 2003), we observed a biphasic concentration-response curve with $\alpha 4$ GFP $\beta 2$ nAChRs (Fig. 5A; Table 2). Following menthol exposure, we observed a $>85 \%$ monophasic concentration-response relationship with an $\mathrm{EC}_{50}$ value of $95.2 \mu \mathrm{M}$ (Fig. 5A; Table 2). This suggests that menthol shifts the stoichiometry of $\alpha 4 \beta 2 \mathrm{nAChRs}$ toward a lower-sensitivity assembly $\left[(\alpha 4)_{3}(\beta 2)_{2}\right]$. It is important to note that the $(\alpha 4)_{3}(\beta 2)_{2}$ stoichiometry also has an inherent robust response to low agonist concentrations (Harpsøe et al., 2011; Wang et al., 2015), for instance, those produced by nicotine during smoking.

In cells transiently transfected with $\alpha 6-\mathrm{GFP}, \beta 2$, and $\beta 3$ nAChR subunits, ACh produced a monophasic concentrationresponse curve with an $\mathrm{EC}_{50}$ value of $0.2 \mu \mathrm{M}$ (Fig. 5C; Table 3), which is similar to previous observations (Henderson et al., 2014). Following menthol treatment, we observed a biphasic concentration-response relationship with $\mathrm{EC}_{50}$ values of 0.17 and $65.0 \mu \mathrm{M}$ (Fig. 5C; Table 3). As noted above, multiple stoichiometries of $\alpha 6 \beta 2^{*}$ nAChRs are not well characterized, but it is likely that the two stoichiometries are $\alpha 6 \beta 2 \beta 3$ and $\alpha 6 \beta 2$ (non$\beta 3)$ nAChRs. To compare this biphasic curve to a "pure" population of $\alpha 6 \beta 2$ (non- $\beta 3$ ) nAChRs, we used a mutant $\beta 2 \mathrm{nAChR}$ subunit $\left(\beta 2_{\mathrm{DM}}\right)$ that enhances exit from the endoplasmic reticulum and therefore enhances PM nAChRs levels (Srinivasan et al., 2011; Xiao et al., 2011; Henderson et al., 2014). ACh produced a monophasic concentration-response relationship curve on $\alpha 6 \beta 2_{\mathrm{DM}} \mathrm{nAChRs}$ with an $\mathrm{EC}_{50}$ value of $35.9 \mu \mathrm{M}$, resembling the less-sensitive phase of the menthol condition's responses (Fig. $5 C$; Table 3). Thus, the biphasic dose-response relationship pro- duced by menthol likely represents a mixed population of $\alpha 6 \beta 2 \beta 3$ and $\alpha 6 \beta 2$ nAChRs.

In addition to using concentration-response assays, we also used FRET to study menthol's effect on nAChR assembly and stoichiometry (Fig. $5 B_{1}, B_{2}, D_{1}, D_{2}$ ). Donor recovery after acceptor photobleaching was used with Neuro-2a cells transiently expressing $\alpha 4$-GFP $\alpha 4$-mCherry $\beta 2$ nAChRs, treated with no drug or with menthol (500 nM, $24 \mathrm{~h})$. We observed an increase in FRET between $\alpha 4$-GFP and $\alpha 4$-mCherry nAChR subunits following $24 \mathrm{~h}$ treatment with menthol (Fig. $5 B_{1}, B_{2}$ ). This suggests that chronic menthol treatment increases the number of lower-sensitivity $(\alpha 4)_{3}(\beta 2)_{2} \mathrm{nAChRs}$ and supports the results from the concentration-response studies with $\alpha 4 \beta 2$ nAChRs (Fig. $5 A$ ).

To continue studying menthol-induced changes in $\alpha 6 \beta 2^{*}$ nAChRs, Neuro-2a cells transiently expressing $\alpha 6$-mCherry $\beta 2 \beta 3$-YFP nAChRs were treated with no drug or with menthol $\left(500 \mathrm{~nm}, 24 \mathrm{~h}\right.$; Fig. $\left.5 D_{1}, D_{2}\right)$. The FRET intensity between $\alpha 6$ mCherry and $\beta 3$-YFP subunits decreased following $24 \mathrm{~h}$ menthol treatment (Fig. $5 D_{1}, D_{2}$ ). This suggests that $\alpha 6 \beta 2^{*}$ nAChRs shift to the lower-sensitivity $\alpha 6 \beta 2$ (non- $\beta 3$ ) nAChR assembly after chronic treatment with menthol and support our observations in the concentration-response studies with $\alpha 6 \beta 2 \beta 3$ nAChRs (Fig. 5C).

Previous studies show that nicotine stabilizes highersensitivity $\alpha 4 \beta 2^{\star}$ nAChRs (Kuryatov et al., 2005; Vallejo et al., 2005; Srinivasan et al., 2011), and this is likely an important mechanism involved in nicotine reward, sensitization, and tolerance (Tapper et al., 2004; Nashmi et al., 2007; Govind et al., 2009). Given that menthol instead stabilizes lower-sensitivity nAChRs, this may explain how long-term menthol exposure, before nicotine, may prevent or abolish nicotine reward-related behavior. It is possible that the menthol-induced stabilization of lower-sensitivity nAChRs (Fig. $5 E, F$ ) prevents the necessary stabilization and activation of higher-sensitivity nAChRs.

\section{Long-term menthol treatment alters $n A C h R$ desensitization}

To understand further how long-term menthol alone may abrogate nicotine reward-related behavior, we began to study additional functional characteristics of nAChRs and how they are altered by exposure to menthol. We used Neuro-2a cells transiently transfected with specific nAChRs to study $\alpha 4 \beta 2$ and $\alpha 6 \beta 2 \beta 3$ nAChRs. Neuro-2a cells transiently transfected with $\alpha 4$ eGFP $\beta 2$ or $\alpha 6$-eGFP $\beta 2 \beta 3$ nAChRs were treated with no drug or with menthol ( $500 \mathrm{nM}, 24 \mathrm{~h})$. We first verified that acute administration of menthol $(\leq 4 \mu \mathrm{M})$ did not affect peak current amplitude or decay kinetics of $\alpha 6 \beta 2 \beta 3 \mathrm{nAChRs}$ (data not shown). Hans et al. (2012) established that acute menthol does not significantly alter $\alpha 4 \beta 2 \mathrm{nAChR}$ function at $\leq 4 \mu \mathrm{M}$. Menthol treatment ( $24 \mathrm{~h}, 500 \mathrm{nM}$ ) had no effect on the peak current amplitude of $\alpha 4$-eGFP $\beta 2$ nAChRs when stimulated by $300 \mu \mathrm{M}$ ACh (Fig. $\left.6 A_{1}, A_{2}, B_{1}\right)$. We also assessed whether acute exposure to menthol altered the deactivation kinetics of $\alpha 4 \beta 2 \mathrm{nAChRs}$ using $10 \mathrm{~s}$ applications of $300 \mu \mathrm{M}$ ACh (Fig. $6 B_{1}, B_{2}$ ). Menthol did not alter the shape of $\alpha 4$-GFP $\beta 2 \mathrm{nAChR}$ waveforms (Fig. $6 B_{1}$ ), including the decay time constant (Fig. $6 B_{2}$ ).

Next, we assessed menthol's effect on the functional properties of $\alpha 6 \beta 2 \beta 3$ nAChRs. Twenty-four hour exposure to submicromolar menthol led to a significant decrease $(p<0.005)$ in the peak current amplitude of $\alpha 6-\operatorname{eGFP} \beta 2 \beta 3$ nAChRs (Fig. $\left.6 C_{1}, C_{2}, D_{1}\right)$. Although the peak amplitude decreased following chronic treatment with menthol, the $\alpha 6$-eGFP $\beta 2 \beta 3$ nAChRs retained a phase that desensitized partially, with a time constant of 

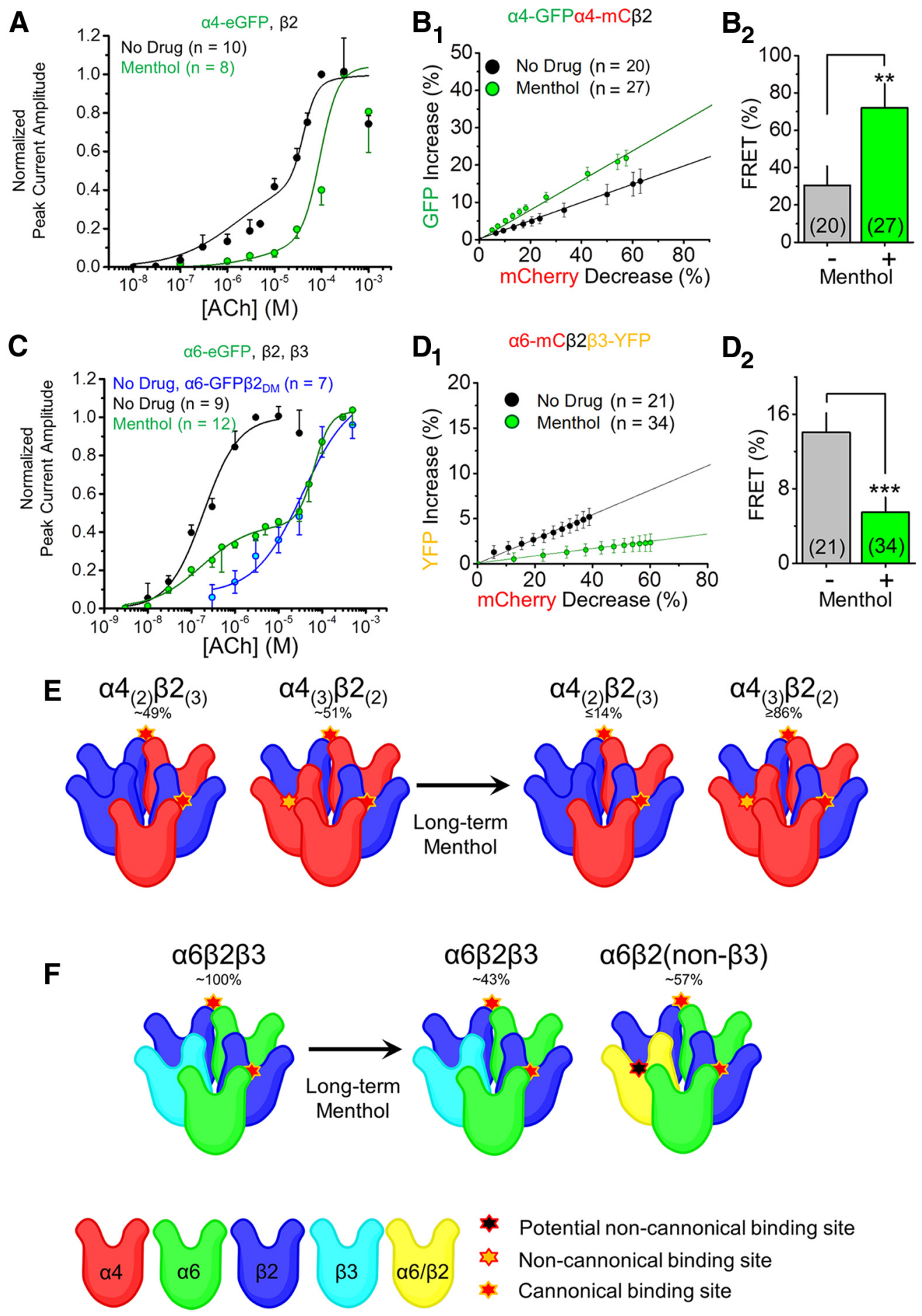

Potential non-cannonical binding site

s Non-cannonical binding site

* Cannonical binding site

Figure 5. Chronic menthol alters nAChR stoichiometry and favors low-sensitivity nAChRs. A, Concentration-response curves of Neuro-2a cells transfected with $\alpha 4$-eGFP $\beta 2 \mathrm{nAChRs}$ treated with no drug (black) or with menthol (red; $24 \mathrm{~h}, 500 \mathrm{~nm}$ ). C, Concentration-response curves of Neuro-2a cells transfected with $\alpha 6$-eGFP, $\beta 2$, and $\beta 3$ nAChR subunits treated with no drug (black), with menthol (red), or with $\alpha 6$-eGFP $\beta 2_{\mathrm{DM}} \mathrm{nAChRs}$ with no drug (blue). $\boldsymbol{B}_{1}, \boldsymbol{D}_{1}$, Linear plot of donor dequenching versus acceptor (mCherry) photodestruction for no drug and for menthol (24h, $500 \mathrm{nM}$ ) treatments. $\boldsymbol{B}_{2}, \boldsymbol{D}_{2}$, Mean FRET efficiency. FRET efficiency was calculated from the linear plot shown in $\boldsymbol{B}_{\mathbf{1}}$ and $\boldsymbol{D}_{\mathbf{1}}$ as described previously (Drenan et al., 2008a; Nichols et al., 2014). $\boldsymbol{B}_{\mathbf{2}}, \boldsymbol{D}_{2}$, Data are mean \pm SEM; ${ }^{* *} p<0.01 ; * * * 0.001$ (unpaired $t$ test). $\boldsymbol{E}$, $\boldsymbol{F}$, Summary of menthol-induced changes in nAChR stoichiometry. $\boldsymbol{E}, \alpha 4 \beta 2$ nAChRs assemble in two stoichiometries: $(\alpha 4)_{2}(\beta 2)_{3}$ and $(\alpha 4)_{3}(\beta 2)_{2}$. We found that under no drug treatment the $\alpha 4 \beta 2 \mathrm{nAChR}$ pool is mixed. Following $24 \mathrm{~h}$ menthol treatment, $\alpha 4 \beta 2 \mathrm{nAChRs}$ assemble almost entirely in the low-sensitivity $(\alpha 4)_{3}(\beta 2)_{2}$ stoichiometry. $F, \alpha 6 \beta 2 \beta 3 \mathrm{nAChRs}$ assemble efficiently under no drug treatment, but following $24 \mathrm{~h}$ menthol treatment the receptor pool is changed to a mixture of $\alpha 6 \beta 2 \beta 3$ and $\alpha 6 \beta 2 \mathrm{nAChRs}$. Number in parenthesis indicates $n$ value.

$\sim 8 \mathrm{~s}$ (Fig. $\left.6 D_{1}, D_{2}\right) . \alpha 6 \beta 2$ (Non- $\beta 3$ ) nAChRs are not preferentially assembled when $\beta 3^{*} \mathrm{nAChR}$ subunits are available (Tumkosit et al., 2006), but they exhibit smaller peak current amplitudes (Xiao et al., 2011; Henderson et al., 2014) that resem- ble our observations following menthol treatment (Fig. $6 C_{1}, C_{2}$ ). The decrease in peak current amplitude (Fig. $6 C_{1}, C_{2}$ ) is not due to acute antagonism, but rather is likely due to the change in $\alpha 6^{*}$ nAChR stoichiometry (Fig. 5). 
Table 2. Concentration-response analysis reveals that chronic menthol alters $\alpha 4 \beta 2$ nAChR stoichiometry

\begin{tabular}{lcc}
\hline & \multicolumn{2}{l}{ Treatment condition } \\
\cline { 2 - 3 } & $\alpha 4$-GFP $\beta 2$ no drug & $\alpha 4-G F P \beta 2+$ menthol \\
\hline $\mathrm{EC}_{50}$ value (higher sensitivity) & $1.8 \pm 3.1 \mu \mathrm{M}$ & $7.8 \pm 4.9 \mu \mathrm{M}$ \\
$n_{h}$ (higher) & 0.645 & 0.57 \\
$\mathrm{EC}_{50}$ value (lower sensitivity) & $41.9 \pm 4.7 \mu \mathrm{m}^{a}$ & $95.2 \pm 14.0 \mu \mathrm{m}^{a, b}$ \\
$n_{h}$ (lower) & 2.2 & 2.2 \\
Higher fraction & 0.49 & 0.14 \\
\hline
\end{tabular}

Values are represented as mean \pm SEM.

${ }^{a} \mathrm{EC}_{50}$ values are statistically different from HS $\alpha 4$-GFP $\beta 2 \mathrm{nAChRs} \mathrm{(no} \mathrm{drug).} p<0.005$, unpaired $t$ test. ${ }^{b} \mathrm{EC}_{50}$ values are statistically different from lower-sensitivity $\alpha 4$-GFP $\beta 2 \mathrm{nAChRs}$ (no drug). $p<0.005$, unpaired $t$ test.

Table 3. Concentration-response analysis reveals that chronic menthol alters $\alpha 6 \beta 2 *$ nAChR stoichiometry

\begin{tabular}{llll}
\hline & \multicolumn{2}{l}{ Treatment condition } & \\
\cline { 2 - 4 } & $\begin{array}{l}\alpha 6-\mathrm{GFP}, \beta 2, \beta 3 \\
\text { no drug }\end{array}$ & $\begin{array}{l}\alpha 6-\mathrm{GFP} \beta 2_{\mathrm{DM}} \\
\text { no drug }\end{array}$ & $\begin{array}{l}\alpha 6-\mathrm{GFP}, \beta 2, \beta 3+ \\
\text { menthol }\end{array}$ \\
\hline $\begin{array}{l}\mathrm{EC}_{50} \text { value (higher } \\
\text { sensitivity) }\end{array}$ & $0.20 \pm 0.07 \mu \mathrm{M}$ & - & $0.17 \pm 0.04 \mu \mathrm{m}$ \\
$\begin{array}{l}n_{h} \text { (higher) } \\
\mathrm{EC}_{50} \text { value (lower } \\
\quad \text { sensitivity) }\end{array}$ & - & - & 0.78 \\
$\begin{array}{l}n_{h} \text { (lower) } \\
\text { Higher fraction }\end{array}$ & - & $35.9 \pm 20.7 \mu \mathrm{m}^{a}$ & $65.0 \pm 4.7 \mu \mathrm{m}^{a}$ \\
\hline
\end{tabular}

Values are represented as mean \pm SEM.

${ }^{a} \mathrm{EC}_{50}$ values are statistically different from $\alpha 6$-GFP $\beta 2 \beta 3 \mathrm{nAChRs}$ (no drug). $p<0.005$, unpaired $t$ test.

Interestingly, menthol (500 nM, $24 \mathrm{~h})$ did increase $\alpha 6 \beta 2$ nAChR peak current amplitude by twofold (Fig. $7 A, B_{1}, B_{2}$ ). TIRFM revealed that menthol treatment resulted in a $>2$-fold increase in $\alpha 6$-SEP $\beta 2$ nAChR PMID (Fig. $7 C$ ). Here, menthol differs from nicotine, as nicotine is unable to upregulate $\alpha 6 \beta 2$ (non- $\beta 3$ ) nAChR number or function (Henderson et al., 2014). These results support our previous observations (Fig. 5) and suggest that menthol may selectively upregulate $\alpha 6 \beta 2$ nAChRs, causing a shift from primarily $\alpha 6 \beta 2 \beta 3 \mathrm{nAChRs}$ to a mixture of $\alpha 6 \beta 2$ and $\alpha 6 \beta 2 \beta 3$ nAChRs.

Next we began to study how menthol may alter nAChR desensitization (Fig. 6E,F). We desensitized $\alpha 4 \beta 2$ and $\alpha 6 \beta 2 \beta 3$ $n A C h R s$ transiently transfected in Neuro-2a cells using bath perfusion of $1 \mu \mathrm{M}$ nicotine. After $10 \mathrm{~min}$, perfusion with nicotine was stopped and the nAChRs were allowed to recover for $20 \mathrm{~min}$. The flow rates were kept constant for all experiments to ensure that any differences would not be altered by washout rates of nicotine. The $\alpha 4 \beta 2$ nAChRs desensitized completely during nicotine exposure and recovered only $20 \%$ of peak current amplitudes (Fig. $6 E$ ). Menthol-treated ( $24 \mathrm{~h}, 500 \mathrm{nM}) \alpha 4 \beta 2 \mathrm{nAChRs}$ exposed to nicotine desensitized, but not completely, and recovered $\sim 80 \%$ of their function (Fig. $6 E$ ).

The $\alpha 6 \beta 2 \beta 3$ nAChRs desensitized completely during nicotine application, then recovered to $40 \%$ of peak function (Fig. $6 F$ ). Menthol-treated $\alpha 6 \beta 2 \beta 3 \mathrm{nAChRs}$ desensitized rapidly and recovered $60 \%$ of function (Fig. $6 F$ ). The rate of recovery, following chronic menthol treatment, was faster when compared with no drug treatment $(p<0.05)$, but maximal recovery did not differ significantly between chronic menthol and no drug treatments. These data suggest that chronic exposure to menthol may protect nAChRs from complete desensitization and provide additional insight into how menthol alters nicotine reward-like behavior.
Menthol action on $n A C h R s$ begins in early exocytotic pathways Recent data show that upregulation of $\mathrm{nAChRs}$ by nicotine requires the intracellular cycling of receptors between the Golgi and the endoplasmic reticulum (Henderson et al., 2014). To determine whether upregulation by menthol also requires Golgi-endoplasmic reticulum cycling, we used a previously characterized drug, CI-976, which inhibits coatomer protein complex I (COPI)-mediated retrograde trafficking (Yang et al., 2011; Henderson et al., 2014). Neuro-2a cells expressing $\alpha 4-$ SEP $\beta 2$ and $\alpha 6$-SEP $\beta 2 \beta 3$ nAChRs were treated with no drug, with $500 \mathrm{nM}$ menthol, with $20 \mu \mathrm{M}$ CI-976, or with both drugs (Fig. 8A,B). Both $\alpha 4$-SEP $\beta 2$ and $\alpha 6$-SEP $\beta 2 \beta 3$ nAChRs displayed an increase in PMID following treatment with $500 \mathrm{nM}$ menthol (Fig. $8 A_{2}, B_{2}$ ). Treatment with CI-976 alone did not change the basal PMID of either $\alpha 4$-SEP $\beta 2$ or $\alpha 6$-SEP $\beta 2 \beta 3$ nAChRs (Fig. $8 A_{2}, B_{2}$ ). Following treatment with both menthol and CI-976, we observed no increase in the PMID of $\alpha 4$-SEP $\beta 2$ or $\alpha 6$-SEP $\beta 2 \beta 3$ nAChRs (Fig. $\left.8 A_{2}, B_{2}\right)$. This suggests that, like effects of nicotine, the increase of $\mathrm{nAChR}$ number produced by menthol requires the cycling of nAChRs between the Golgi and endoplasmic reticulum.

Nicotine upregulates $\mathrm{nAChRs}$ by binding to and chaperoning nAChRs located in the endoplasmic reticulum (Kuryatov et al., 2005; Sallette et al., 2005; Henderson and Lester, 2015). The later exocytotic machinery then moves these nAChRs to the PM (Whiteaker et al., 1998; Sallette et al., 2005; Srinivasan et al., 2011). The formation of endoplasmic reticulum exit sites (ERES) with nicotine is an indicator of an event closely following the nAChR chaperoning process. To determine whether menthol causes a similar increase in ERES, we quantified the formation of condensed ERES following chronic treatment with menthol (Fig. $8 C, D)$. Neuro-2a cells were cotransfected with $\alpha 4$-mCherry $\beta 2$ or $\alpha 6$-mCherry $\beta 2 \beta 3$ nAChRs and with Sec24D-eGFP (a marker for active ERES) and the density of $\alpha 4$-mCherry ${ }^{\star}$ and $\alpha 6$-mCherry ${ }^{\star}$ nAChRs inside ERES was calculated (Fig. $8 C, D)$. Menthol elicited a twofold increase of $\alpha 4 \beta 2$ nAChRs in ERES $(p<0.05)$ and a threefold increase in $\alpha 6 \beta 2 \beta 3$ nAChRs in ERES ( $p<0.005$; Fig. $8 D$ ). Therefore menthol, like nicotine, increases ERES in addition to the increase in $\mathrm{nAChR}$ number.

TRP channels do not mediate chronic menthol effects on nAChRs Menthol is most known as a potent ligand for TRP channels. While we believe that the actions we observed in mouse brain slices, cultured neurons, and heterologous systems arise, directly or indirectly, from effects on nAChRs, we devised experiments to determine whether TRP channels also played a role (Table 4).

We used RNA sequencing to assess the presence of mRNAs for TRP channels in adult mice, cultured midbrain neurons, and Neuro-2a cells. In laser-capture microdissected DA neurons from the SNc of adult mice, we detected mRNA from $>10,000$ genes at levels $>0.1$ FPKM (Henley et al., 2013). We also identified DA neurons in cultures from embryonic mouse midbrains, using either TH-eGFP mice from GENSAT (Gong et al., 2003) or nAChR 33 -GFP mice (Shih et al., 2014; as in Fig. 3). In these cultured DA neurons, we detected mRNA for $>8000$ genes at levels >0.1 FPKM (Henley et al., 2013; Srinivasan et al., 2016). In DA neurons from both adult mouse and midbrain cultures, TRPA1, TRPV1, and TRPM8 transcript levels were $<0.1$ FPKM. In Neuro-2a cells, TRPA1, TRPV1, and TRPM8 were not detected (Table 4). Because mRNAs for the major TRP channels sensitive to menthol are undetectable, we conclude that the observed effects with menthol in mouse brain (Figs. 1, 2), cultured DA neurons (Figs. 2, 3), or Neuro-2a cells (Figs. 1, 5-8) were not mediated by TRP channels. 


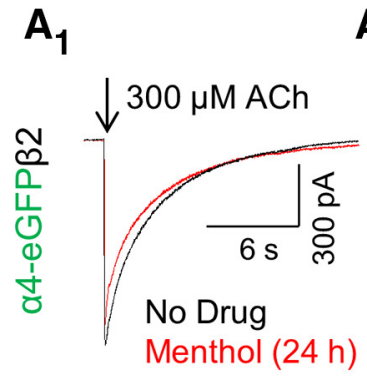

$\mathbf{A}_{2}$

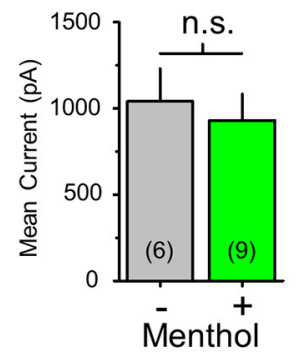

$B_{1}$

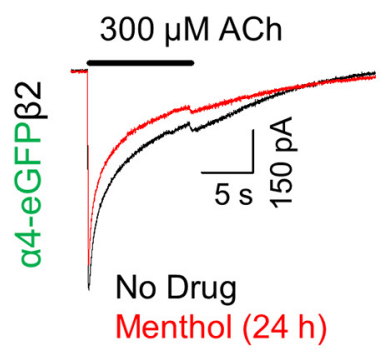

$\mathrm{B}_{2}$

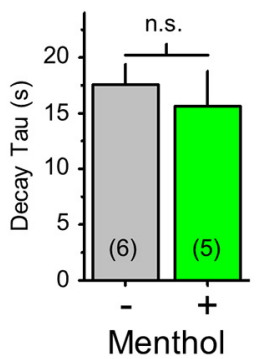

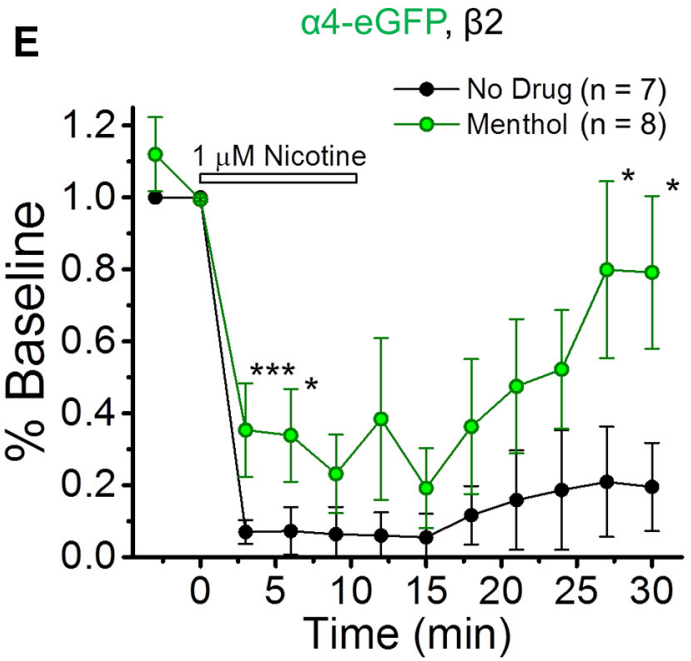

$\mathrm{C}_{2}$
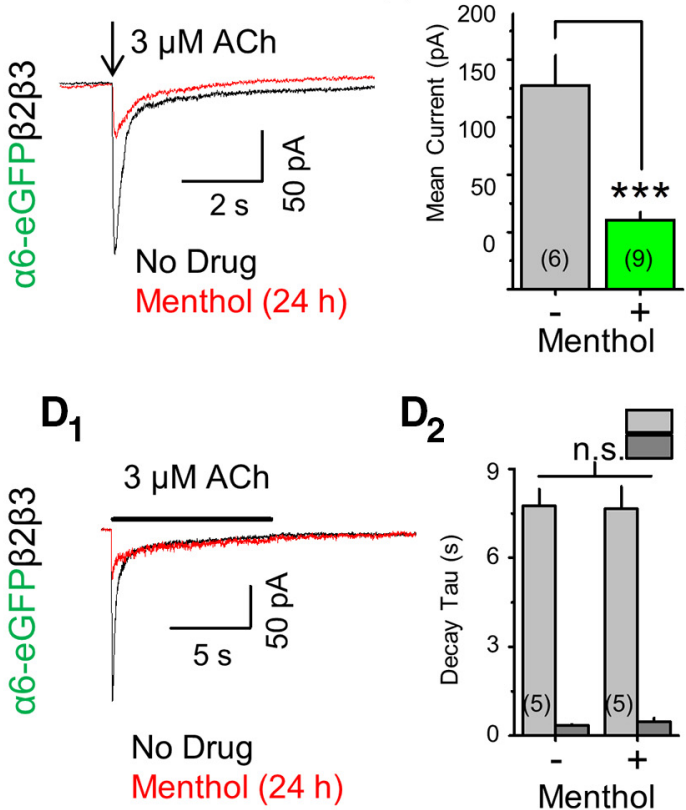

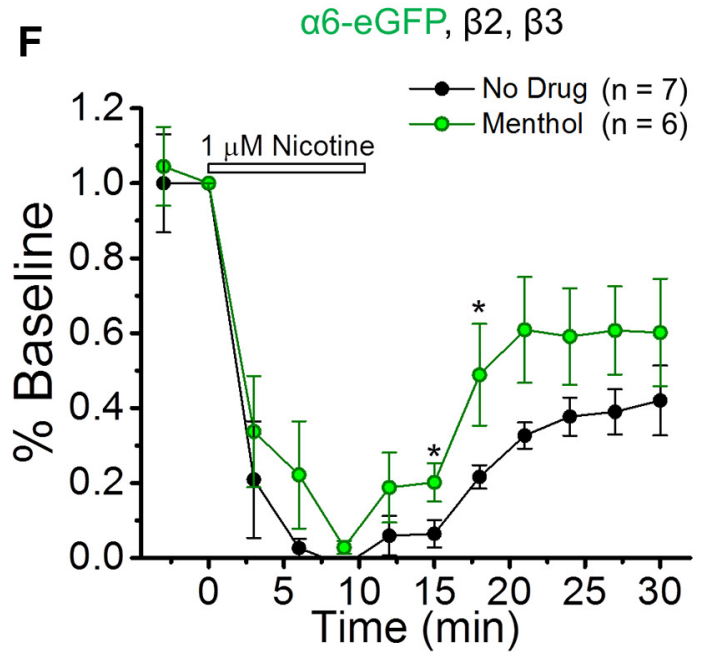

Figure 6. Long-term menthol decreases $\alpha 6 \beta 2 \beta 3$ nAChR peak current amplitude and alters $\alpha 4^{*}$ and $\alpha 6^{*}$ nAChR desensitization. $\boldsymbol{A}_{\mathbf{1}}, \boldsymbol{B}_{1}, \boldsymbol{C}_{1}, \boldsymbol{D}_{1}$, Mean waveforms recorded from Neuro-2a cells expressing $\alpha 6$-eGFP $\beta 2 \beta 3$ or $\alpha 4$-eGFP $\beta 2$ nAChRs in the absence or presence of menthol ( $24 \mathrm{~h}, 500 \mathrm{~nm}) . \boldsymbol{A}_{\boldsymbol{1}}, \boldsymbol{C}_{\boldsymbol{1}}, 300 \mathrm{~ms}$ puff of ACh. $\boldsymbol{B}_{\boldsymbol{1}}, \boldsymbol{D}_{\boldsymbol{1}}, 10 \mathrm{~s}$ puff of ACh. $\boldsymbol{B}_{\boldsymbol{1}}, 10 \mathrm{~s}$ puffs reveal a sustained rebound current that is likely caused by recovery from agonist-mediated channel block. $\boldsymbol{A}_{2}, \boldsymbol{C}_{2}$, Mean of peak amplitude of 300 ms puffs. $\boldsymbol{B}_{2}, \boldsymbol{D}, \boldsymbol{D}_{2}$, Mean decay time constants for $10 \mathrm{~s}$ puffs. Numbers in parenthesis indicate $n$ value. $\boldsymbol{E}, \boldsymbol{F}, \alpha 4-\mathrm{GFP} \beta 2$ and $\alpha 6$-GFP $\beta 2 \beta 3 \mathrm{nAChRs}$ treated with no drug (black) or with menthol (green). nAChRs were desensitized with $1 \mu \mathrm{m}$ nicotine (10 min) and then allowed to recover. In all panels, data are mean \pm SEM; ${ }^{*} p<0.05 ;{ }^{* * *} p<0.005$ (unpaired $t$ test). In all cases, menthol treatment was $24 \mathrm{~h}, 500 \mathrm{~nm}$. In all cases, menthol-containing media was removed at the start of assays. Number in parenthesis indicates $n$ value.

We also experimented with icilin, a well characterized TRPM8 and TRPA1 ligand. In Neuro- $2 \mathrm{a}$ cells expressing $\alpha 4$ SEP- $\beta 2$ $\mathrm{nAChRs}$, we tested five icilin concentrations ranging from 50 to $20 \mu \mathrm{M}$, applied for $24 \mathrm{~h}$. Icilin had no significant effect on $\mathrm{nAChR}$ number (Fig. 9). Therefore, we believe that the effects of chronic exposure to $500 \mathrm{~nm}$ menthol (Figs. $1 G, H, 5-8$ ) are not mediated by TRP channels.

\section{Discussion}

Does menthol abolish nicotine reward-related behavior? Interestingly, menthol applied long-term before nicotine exposure inhibits nicotine reward-related behavior. Long-term nicotine exposure results in several well characterized neurobiological and pharmacological consequences: (1) nAChR numbers are in- creased (Richards et al., 2011; Srinivasan et al., 2011; Henderson et al., 2014); (2) the "upregulated" nAChRs exhibit a higher sensitivity to nicotine (Kuryatov et al., 2005; Govind et al., 2012; Henderson and Lester, 2015); and (3) the cell-specific upregulation leads to changes in reward-related DA release (Nashmi et al., 2007; Sulzer, 2011; Faure et al., 2014). Additionally, activation of these higher-sensitivity nAChRs is likely both necessary and sufficient to initiate nicotine reward-related behavior (Tapper et al., 2004; Nashmi et al., 2007; Faure et al., 2014).

We observed that menthol, in the absence of nicotine, exerts changes in $\mathrm{nAChR}$ number, assembly, and function, which differ from sequelae previously described for nicotine. Menthol's actions on $\mathrm{nAChR}$ assembly are opposite to the actions of nicotine. 

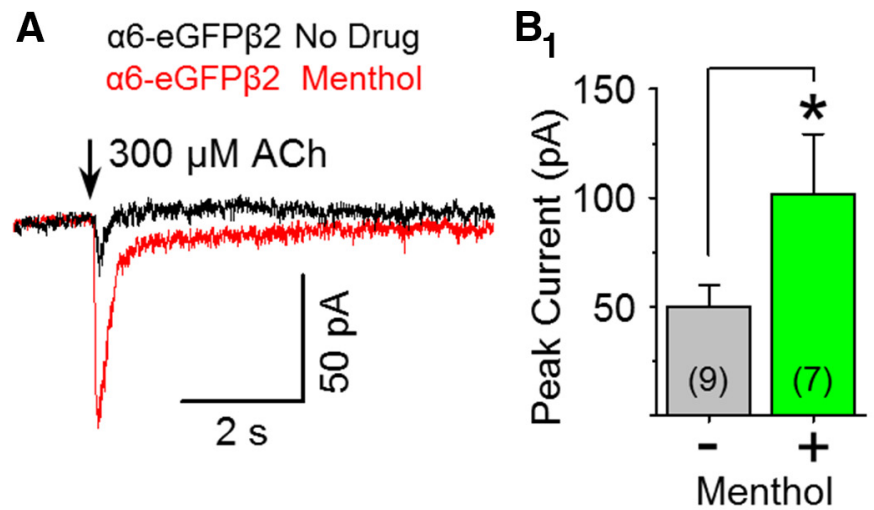
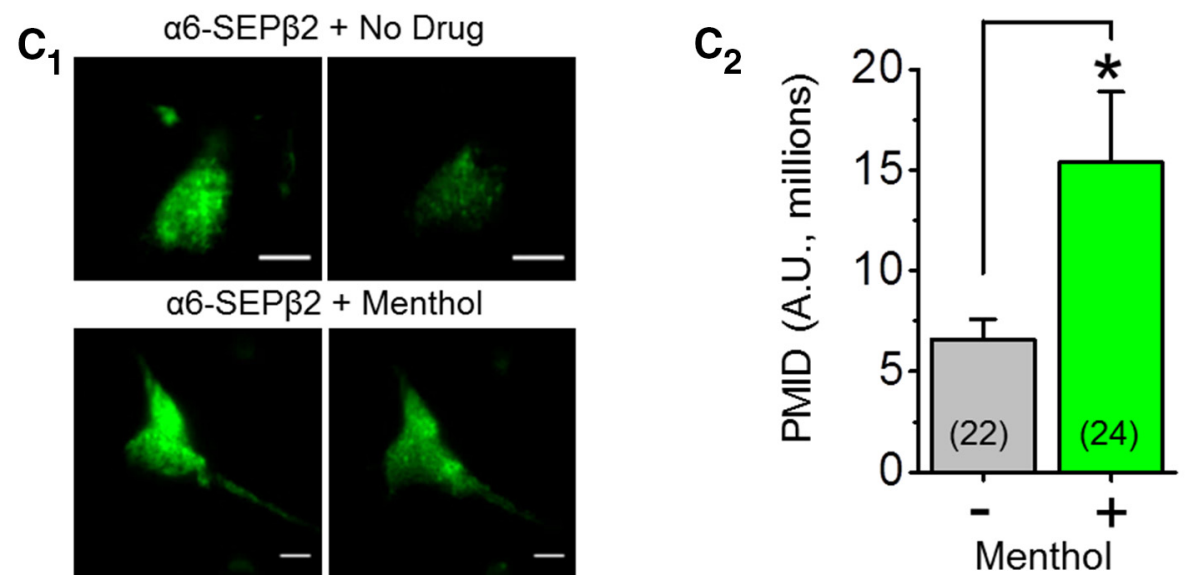

Figure 7. Menthol upregulates $\alpha 6 \beta 2$ (non- $\beta 3$ ) nAChRs. Neuro-2a cells were transfected with $\alpha 6$-eGFP and $\beta 2 \mathrm{nAChR}$ subunits. Where indicated, menthol (500 nM) was present for $24 \mathrm{~h}$ before imaging. $\boldsymbol{A}$, Representative traces showing $300 \mu \mathrm{m}$ ACh-induced currents for cells treated with no drug or with menthol $(24 \mathrm{~h}, 500 \mathrm{~nm})$. $\boldsymbol{B}_{1}, \boldsymbol{B}_{2}$, Summary of peak current and percentage of cells exhibiting function. $\boldsymbol{C}_{1}$, Representative TIRF images. Scale bars, $10 \mu \mathrm{m}$. In each panel, left image is at pH 7.4 and right is the same cell imaged at pH 5.4. $\boldsymbol{C}_{2}$, Mean PMID (mean \pm SEM). $\boldsymbol{B}_{1}, \boldsymbol{C}_{2}$, $p<$ 0.05 , unpaired $t$ test. Number in parenthesis indicates $n$ value.

Instead of stabilizing higher-sensitivity nAChRs, menthol stabilized lower-sensitivity nAChRs, according to our observations. Menthol also exhibited cell-specific upregulation of midbrain $\alpha 4^{\star}$ nAChRs that differs from effects of nicotine. Nicotine robustly upregulates $\alpha 4^{*}$ nAChRs on SNr and VTA GABA neurons (Nashmi et al., 2007); in contrast, menthol upregulates $\alpha 4^{*}$ nAChRs on SNc and VTA DA neurons (Fig. 10). The nicotineinduced, cell-specific upregulation of $\alpha 4^{\star}$ nAChRs on GABAergic neurons provides an increased inhibitory tone on midbrain DA neurons of the VTA and SNc (Nashmi et al., 2007; Xiao et al., 2009). This increased inhibition results in decreased activity of the target DA neurons and a decrease in tonic DA release in the nucleus accumbens. Acute nicotine exposure causes a rebound disinhibition that results in increased phasic DA release, driving reward and reinforcement (Faure et al., 2014). Since menthol does not alter $\alpha 4^{*}$ nAChR number on GABAergic neurons of the SNr but upregulates nAChRs on DA neurons of the VTA and $\mathrm{SNc}$, it is possible that nicotine's circuit-based effect on midbrain GABA and DA neurons is partially negated.

The different pharmacology of high-sensitivity and lowsensitivity nAChRs presumably plays a role. Higher-sensitivity nAChRs (stabilized by nicotine) are robustly activated by low concentrations of nicotine ( $<1 \mu \mathrm{M}$; Nelson et al., 2003; Kuryatov and Lindstrom, 2011). Lower-sensitivity $\alpha 4^{*}$ and $\alpha 6^{*}$ nAChRs (stabilized by menthol) are robustly activated by concentrations of nicotine $\geq 30 \mu \mathrm{M}$ (Fig. 5). However, circulating concentrations of nicotine in human smokers (and mice following our adminis- tration protocol) are $100-500 \mathrm{~nm}$. This suggests that long-term menthol alone may reduce the efficacy of circulating nicotine and its acute effects.

We note that menthol altered midbrain DA neurons so that transient $\mathrm{nAChR}$ activation results, via $\mathrm{D} 2 \mathrm{R}$, in a decrease in $\mathrm{DA}$ neuron firing frequency (Fig. 3). This appears to oppose the actions of nicotine (Fig. 10). In summary, long-term menthol treatment alone may reduce or prevent the "burst-like" firing due to nAChR activation by nicotine, important for reward and reinforcement. Reduced burst-like firing may contribute to our findings that menthol alone prevents nicotine reward-related behavior.

These observations occurred with chronic exposure to menthol alone, or in the case of our behavioral studies, menthol alone followed by nicotine during continued maintained exposure to menthol. In other studies, when previously menthol-naive animals are repeatedly coexposed to nicotine plus menthol, there is an enhancement of nicotine reinforcement (Wang et al., 2014) and nicotine withdrawal (Alsharari et al., 2015). Experiments are necessary, and underway, to understand additional cellular and behavioral effects of coexposure to nicotine plus menthol.

\section{Menthol may act directly on midbrain DA neurons}

Previous data show that menthol acts in the lungs (Ahijevych and Garrett, 2010) and alters nicotine metabolism in humans (Benowitz et al., 2004) and mice (Alsharari et al., 2015). Because we observed marked effects by chronic menthol on $\mathrm{nAChR}$ function 
$A_{1}$

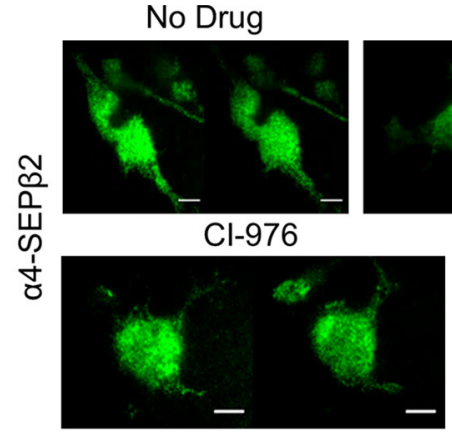

$B_{1}$
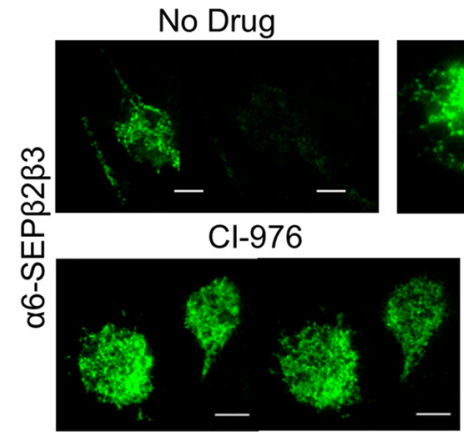

C

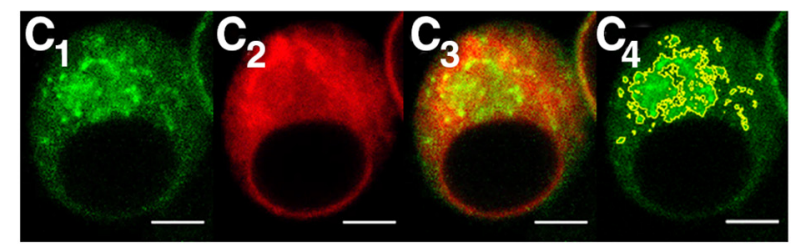

Menthol

$\mathbf{A}_{2}$
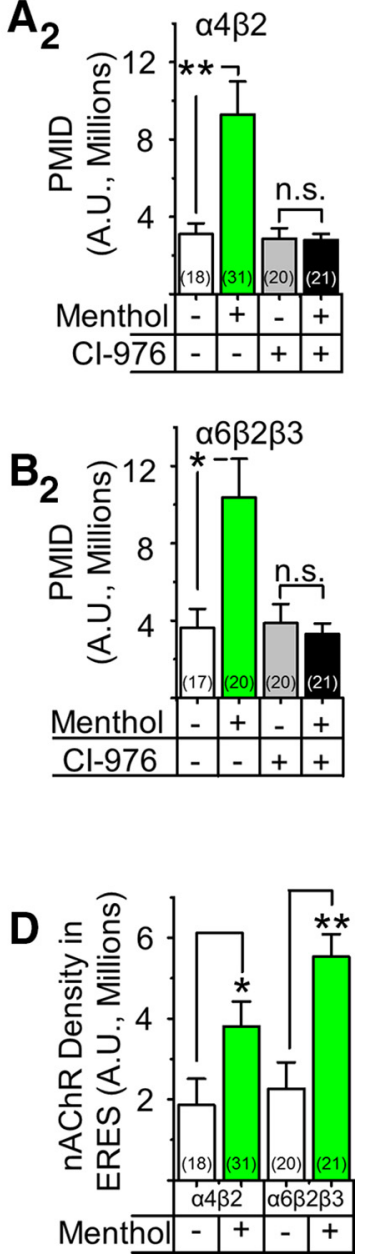

Figure 8. Long-term menthol upregulates nAChRs via endoplasmic reticulum-Golgi trafficking. $A_{1}, A_{2}$, Representative TIRFM images of Neuro-2a cells transfected with $\alpha 4$-SEP plus $\beta 2$ or with $\alpha 6$-SEP plus $\beta 2$ plus $\beta 3 \mathrm{nAChR}$ subunits. Nicotine (50 or $100 \mathrm{~nm})$, menthol ( $500 \mathrm{~nm})$, or Cl-976 $(20 \mu \mathrm{m})$ were present $24 \mathrm{~h}$ before imaging. Scale bars, $10 \mu \mathrm{m}$. In each panel, the left image is at pH 7.4 and right image is the same cell at pH 5.4. $\boldsymbol{B}_{1}, \boldsymbol{B}_{2}$, PMID was quantified for SEP nAChRs. $\boldsymbol{C}_{\mathbf{1}}-\boldsymbol{C}_{\mathbf{4}}$, Representative confocal images of a Neuro-2a cell transfected with $\alpha 6$-mCherry, $\beta 2$, and $\beta 3$ subunits plus Sec24D-eGFP. Scale bars, $5 \mu \mathrm{m}$. $\boldsymbol{C}_{1}$, Sec24D-eGFP fluorescence. $\boldsymbol{C}_{2}, \alpha 6$ Fluorescence. $\boldsymbol{C}_{3}$, Merged $\boldsymbol{C}_{1}$ and $\boldsymbol{C}_{2}$ image. $\boldsymbol{C}_{4}$, ERES demarcated for quantification. $\boldsymbol{D}$, Quantification of the $\alpha 4$-mCherry or $\alpha 6$-mCherry fluorescence in ERES. Data are mean \pm SEM. ${ }^{*} p<0.05$; ${ }^{* *} p<0.005$ (ANOVA, post hoc Tukey's test). Number in parenthesis indicates $n$ value.

Table 4. mRNA profile of TRP family genes

\begin{tabular}{lllll}
\hline Gene & Whole & $\begin{array}{l}\text { Laser-captured single } \\
\text { DA neuron }\end{array}$ & $\begin{array}{l}\text { Single cultured } \\
\text { DA neuron }\end{array}$ & $\begin{array}{l}\text { Neuro-2a } \\
\text { cells }\end{array}$ \\
\hline TRPM8 $^{b}$ & - & - & - & - \\
TRPA1 $^{b}$ & - & - & - & - \\
TRPV1 & - & - & - & - \\
TRPV2 & + & + & + & + \\
TRPM2 & + & + & + & + \\
TRPM7 & + & + & + & + \\
TRPC2 & + & + & + & + \\
TRPMI1 & + & + & + & + \\
\hline
\end{tabular}

${ }^{a}$ From SNc of adult mouse brain.

${ }^{b} \mathrm{~A}$ TRP family gene encoding a menthol-activated channel. ,$+>1.0$ FPKM.

with mice and with cultured DA neurons in the absence of nicotine, we conclude that menthol exerts a neural effect(s) by itself, in addition to modifications that may occur when nicotine is present. In using osmotic minipumps to deliver menthol to mice, we largely avoid the pharmacokinetics of exposure through the lungs. We infer that menthol enters the mouse brain and is present at $<2.5 \mu \mathrm{M}$ after $10 \mathrm{~d}$. Due to our present detection limits, we cannot provide a true concentration of menthol in mouse brains.
This was one motivation to employ cultured midbrain neurons to study the function of native nAChRs on DA neurons with a known concentration of menthol; we observed local actions of menthol at $500 \mathrm{nM}$. Therefore, if menthol alters nicotine metabolism or levels of nicotine, this augments the local actions of menthol alone on midbrain neurons.

\section{Menthol as a candidate chemical chaperone}

Our data show that chronic exposure to low-dose menthol acts on processes also influenced by chronic exposure to low-dose nicotine. These actions occur at the subcellular level, the cellular level, and the behavioral level; but actions differ between nicotine and menthol (Fig. 10). Many mechanistic facts are available about so-called "inside-out" actions of chronic nicotine beginning when nicotine acts as a selective pharmacological chaperone by binding to highly nicotine-sensitive nAChRs within the endoplasmic reticulum and cis-Golgi (Henderson and Lester 2015). Several thermodynamic, pharmacokinetic, and pharmacodynamic properties allow nicotine to function in this way at concentrations orders of magnitude lower than the $\mathrm{EC}_{50}$ value for transiently activating nAChRs on the PM. Now we report that exposure to menthol also appears to act within the early exocytotic pathway, at maintained concentrations orders of magnitude 

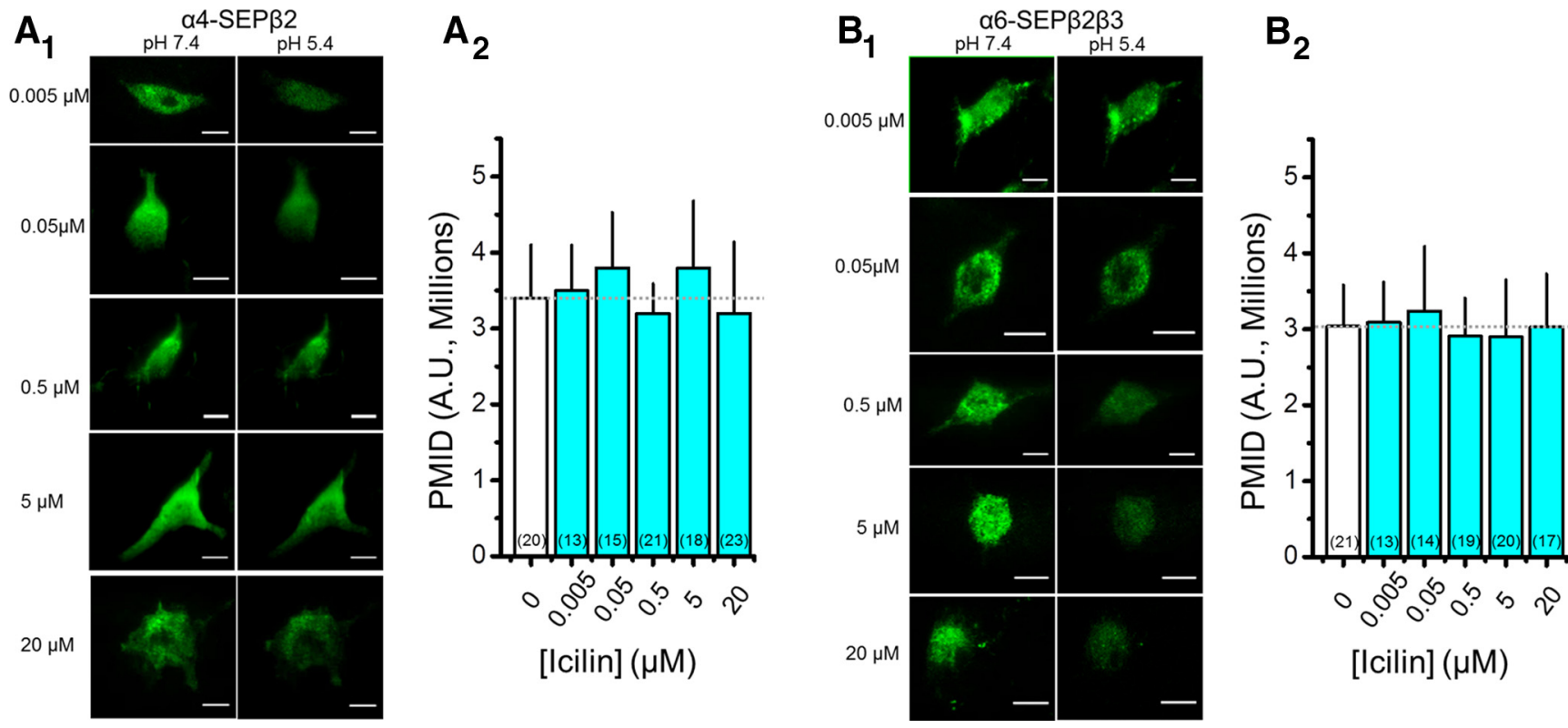

Figure 9. TrpM8 agonist icilin does not alter PM nAChR number. $\boldsymbol{A}_{\boldsymbol{1}}, \boldsymbol{B}_{\boldsymbol{1}}$, Representative TIRFM images of Neuro-2a cells transfected with $\alpha 4$-SEP $\beta 2$ and $\alpha 6$-SEP $\beta 2 \beta 3 \mathrm{nAChRs}$. Icilin, at listed concentrations, was present $24 \mathrm{~h}$ before imaging. Scale bars, $10 \mu \mathrm{m}$. In each panel, the left image is at pH 7.4 and the right image is the same cell at pH 5.4. $A_{2}, B_{2}$, PMID was quantified for SEP nAChRs. Number in parenthesis indicates $n$ value.
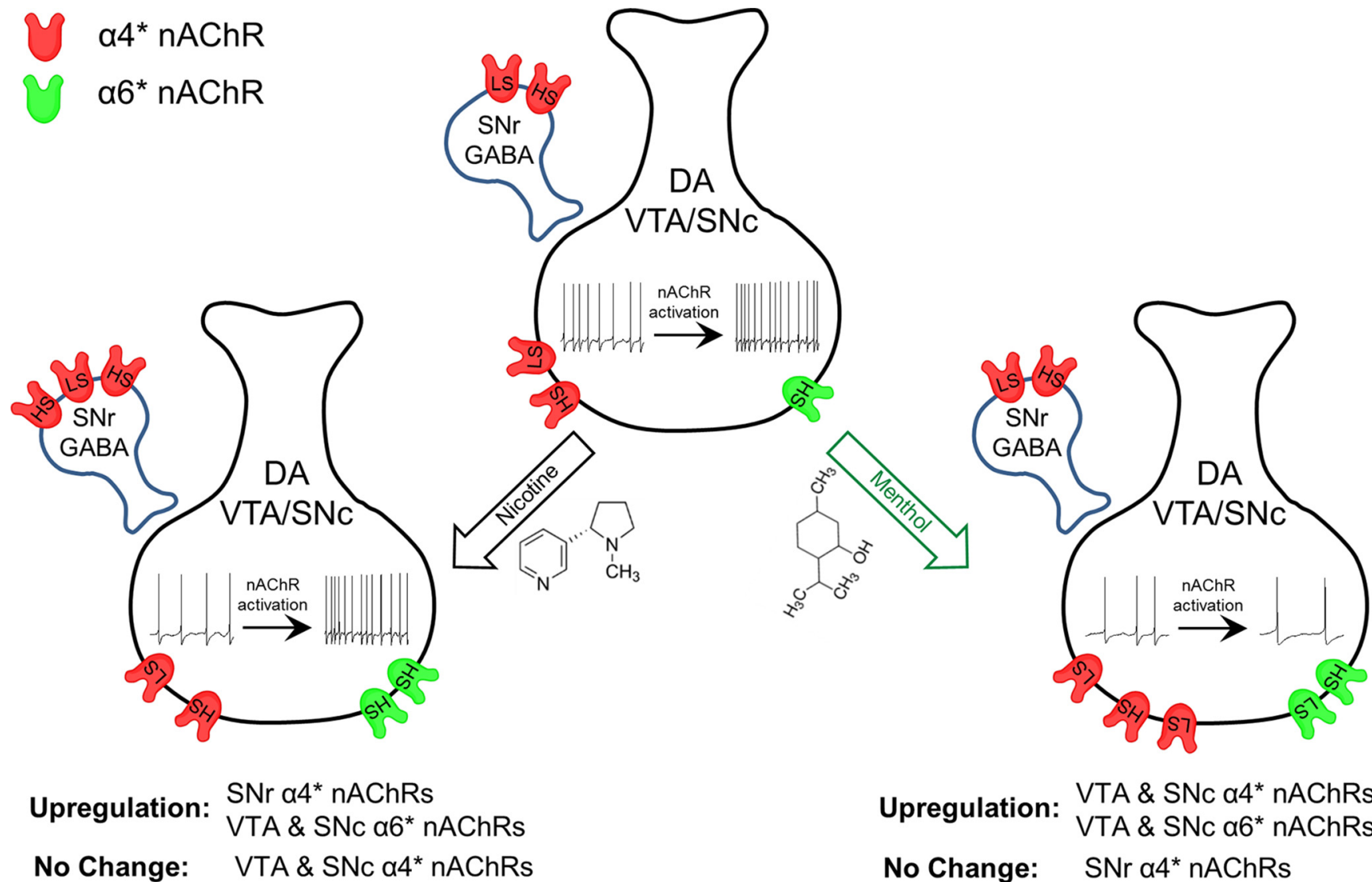

Upregulation: VTA \& SNc $\alpha 4^{*}$ nAChRs
VTA \& SNc $\alpha 6^{*}$ nAChRs

No Change: $\quad$ SNr $a 4^{*}$ nAChRs

Figure 10. Chronic menthol and chronic nicotine differentially alter midbrain DA neurons. Schematic of nAChRs residing in midbrain GABA (SNr) and DA (VTA and SNc) neurons. Nicotine robustly increases higher-sensitivity $\alpha 4^{*}$ nAChR number in SNr GABAergic neurons, but does not change $\alpha 4^{*}$ nAChR number in SNc or VTA DA neurons (Nashmi et al., 2007; Xiao et al., 2009). Long-term nicotine exposure decreases firing frequency of DA neurons, but this is transiently accelerated upon exposure to nAChR agonists (i.e., nicotine; Nashmi et al., 2007; Xiao et al., 2009). Long-term menthol exposure increases lower-sensitivity $\alpha 4^{*}$ and $\alpha 6^{*}$ nAChR number in SNC and VTA DA neurons, but does not alter SNr GABAergic $\alpha 4^{*}$ nAChR number. DA neuron firing frequency, which decreases following long-term menthol exposure, does not accelerate following exposure to nAChR agonists. The opposing effects of nicotine and menthol on midbrain neurons may explain how long-term menthol treatment before nicotine exposure abrogates nicotine reward-related behavior. 
lower than the effective concentrations for transient activation of TRPM8 or for allosteric modulation of Cys-loop receptors (Hans et al., 2012; Ashoor et al., 2013; Ton et al., 2015).

We ruled out participation by TRPM8 or TRPA1, and these concentrations of menthol produce no acute effects on the two classes of nAChRs studied here (Hans et al., 2012). We do not believe that menthol is acting as a selective pharmacological chaperone for nAChRs. "Chemical chaperoning" may more appropriately describe effects of chronic menthol exposure at nAChRs. Chemical chaperones, such as butyrate, 4-pheylbutyric acid, and valproic acid, stabilize partially or improperly folded proteins. These compounds do increase the expression of nAChRs, mostly at micromolar concentrations (Sine et al., 1990; Kuryatov et al., 2013), via post-translational mechanisms. In one case, valproic acid upregulated $\alpha 7 \mathrm{nAChRs}$ in neuroblastoma cells at concentrations just 10-fold higher than the menthol concentrations studied here (Kuryatov et al., 2013). The present data are novel in providing information that a tobacco additive associated with nicotine dependence stabilizes certain nAChR stoichiometries, that the upregulation occurs in vivo, and that the changes have behavioral components.

From electrophysiology and FRET assays, this study shows that menthol alone stabilizes lower-sensitivity $\alpha 4^{\star}$ and $\alpha 6^{*}$ nAChRs. In this effect, menthol phenomenologically resembles the nAChR partial agonist cytisine or the endogenous protein lynx1, which also stabilize lower-sensitivity $(\alpha 4)_{3}(\beta 2)_{2}$ nAChRs (Richards et al., 2012; Srinivasan et al., 2012; Nichols et al., 2014). It is possible that menthol acts like lynx1, which binds to and stabilizes $\alpha-\alpha \mathrm{nAChR}$ interfaces and acts as a chaperone for these $\alpha-\alpha$-containing nAChRs. The FRET methods in this paper are dominated by the nAChRs residing in the endoplasmic reticulum and Golgi, with additional contribution from the PM. Therefore, we know that the receptors existing in the early secretory pathway are also lower-sensitivity $(\alpha 4)_{3}(\beta 2)_{2}$ and $\alpha 6 \beta 2$ (non- $\beta 3$ ) nAChRs following menthol exposure.

However, we lack data proving that menthol exerts its chronic actions on nAChRs by binding directly to those nAChRs. Chemical chaperones have less selective actions than pharmacological chaperones. It is prudent to suppose that menthol binds directly to several proteins, perhaps including nAChRs. In particular, we do not yet know how chronic menthol exposure produces strong coupling between nAChR activation and D2R-mediated GIRK activation.

Although "vehicle" solutions contained ethanol, one asks whether the $60 \%$ ethanol in the osmotic minipumps interacted with the menthol delivered from those pumps. The calculated plasma ethanol concentration was $45-100$-fold lower than that affecting reward-related pathways in other reports (see Materials and Methods). For the cell culture experiments, there was no ethanol. The extensive biochemical and pharmacological correspondences among the in vivo experiments and cultures argue against a synergistic interaction, at the behavioral level, between ethanol and menthol.

\section{Menthol, more than a tobacco flavorant}

According to the estimate that $30 \%$ of the 15 billion cigarettes consumed daily contain menthol, and the assumption that they contain on average $3 \mathrm{mg}$ apiece, one calculates that smokers inhale 15 tons of menthol daily. Along with nicotine, menthol is one of the most inhaled substances on Earth. We have observed that menthol alone can upregulate nAChRs, decrease DA neuron baseline firing, alter $\mathrm{nAChR}$ stoichiometry, alter $\mathrm{nAChR}$ desensitization, increase endoplasmic reticulum exit of nAChRs, and suppress nicotine reward-related behavior. We have observed these effects at estimated pharmacologically relevant levels of menthol, acting locally on midbrain DA neurons relevant to reward-related pathways. Others have shown that menthol may enhance nicotine reinforcement (Wang et al., 2014) and nicotine withdrawal (Alsharari et al., 2015). Thus, emerging data show that menthol may not be just a harmless tobacco additive.

\section{References}

Ahijevych K, Garrett BE (2004) Menthol pharmacology and its potential impact on cigarette smoking behavior. Nicotine Tob Res 6 [Suppl 1]: S17-S28. Medline

Ahijevych K, Garrett BE (2010) The role of menthol in cigarettes as a reinforcer of smoking behavior. Nicotine Tob Res 12 [Suppl 2]:S110-S116. CrossRef Medline

Ai J, Taylor KM, Lisko JG, Tran H, Watson CH, Holman MR (2015) Menthol content in US marketed cigarettes. Nicotine Tob Res pii:mtv162. CrossRef Medline

Alsharari SD, King JR, Nordman JC, Muldoon PP, Jackson A, Zhu AZ, Tyndale RF, Kabbani N, Damaj MI (2015) Effects of menthol on nicotine pharmacokinetic, pharmacology and dependence in mice. PloS One 10:e0137070. CrossRef Medline

Ashley M, Dixon M, Sisodiya A, Prasad K (2012) Lack of effect of menthol level and type on smokers' estimated mouth level exposures to tar and nicotine and perceived sensory characteristics of cigarette smoke. Regul Toxicol Pharmacol 63:381-390. CrossRef Medline

Ashoor A, Nordman JC, Veltri D, Yang KH, Al Kury L, Shuba Y, Mahgoub M, Howarth FC, Sadek B, Shehu A, Kabbani N, Oz M (2013) Menthol binding and inhibition of $\alpha 7$-nicotinic acetylcholine receptors. PloS One 8:e67674. CrossRef Medline

Benowitz NL, Herrera B, Jacob P 3rd (2004a) Mentholated cigarette smoking inhibits nicotine metabolism. J Pharmacol Exp Ther 310:1208-1215. CrossRef Medline

Breese CR, Marks MJ, Logel J, Adams CE, Sullivan B, Collins AC, Leonard S (1997) Effect of smoking history on $[3 \mathrm{H}]$ nicotine binding in human postmortem brain. J Pharmacol Exp Ther 282:7-13. Medline

Brodie M (1991) Low concentrations of nicotine increase the firing rate of neurons of the rat ventral tegmental area in vitro. In: Advances in pharmacological sciences (Adlkoffer F, ed), pp 373-377. Basel: Birkhäuser.

Brody AL, Mandelkern MA, Costello MR, Abrams AL, Scheibal D, Farahi J, London ED, Olmstead RE, Rose JE, Mukhin AG (2009) Brain nicotinic acetylcholine receptor occupancy: effect of smoking a denicotinized cigarette. Int J Neuropsychopharmacol 12:305-316. CrossRef Medline

Brody AL, Mukhin AG, La Charite J, Ta K, Farahi J, Sugar CA, Mamoun MS, Vellios E, Archie M, Kozman M, Phuong J, Arlorio F, Mandelkern MA (2013) Up-regulation of nicotinic acetylcholine receptors in menthol cigarette smokers. Int J Neuropsychopharmacol 16:957-966. CrossRef Medline

Collo G, Bono F, Cavalleri L, Plebani L, Mitola S, Merlo Pich E, Millan MJ, Zoli M, Maskos U, Spano P, Missale C (2013) Nicotine-induced structural plasticity in mesencephalic dopaminergic neurons is mediated by dopamine D3 receptors and Akt-mTORC1 signaling. Mol Pharmacol 83: 1176-1189. CrossRef Medline

Drenan RM, Lester HA (2012) Insights into the neurobiology of the nicotinic cholinergic system and nicotine addiction from mice expressing nicotinic receptors harboring gain-of-function mutations. Pharmacol Rev 64:869-879. CrossRef Medline

Drenan RM, Nashmi R, Imoukhuede P, Just H, McKinney S, Lester HA (2008a) Subcellular trafficking, pentameric assembly and subunit stoichiometry of neuronal nicotinic ACh receptors containing fluorescentlylabeled $\alpha 6$ and $\beta 3$ subunits. Mol Pharmacol 73:27-41. Medline

Drenan RM, Grady SR, Whiteaker P, McClure-Begley T, McKinney S, Miwa JM, Bupp S, Heintz N, McIntosh JM, Bencherif M, Marks MJ, Lester HA (2008b) In vivo activation of midbrain dopamine neurons via sensitized, high-affinity $\alpha 6$ nicotinic acetylcholine receptors. Neuron 60:123-136. CrossRef Medline

Faure P, Tolu S, Valverde S, Naude J (2014) Role of nicotinic acetylcholine receptors in regulating dopamine neuron activity. Neurosci 282:86-100. CrossRef Medline

Gandhi KK, Foulds J, Steinberg MB, Lu SE, Williams JM (2009) Lower quit rates among African American and Latino menthol cigarette smokers at a tobacco treatment clinic. Int J Clin Pract 63:360-367. CrossRef Medline 
Gong S, Zheng C, Doughty ML, Losos K, Didkovsky N, Schambra UB, Nowak NJ, Joyner A, Leblanc G, Hatten ME, Heintz N (2003) A gene expression atlas of the central nervous system based on bacterial artificial chromosomes. Nature 425:917-925. CrossRef Medline

Govind AP, Vezina P, Green WN (2009) Nicotine-induced upregulation of nicotinic receptors: underlying mechanisms and relevance to nicotine addiction. Biochem Pharmacol 78:756-765. CrossRef Medline

Govind AP, Walsh H, Green WN (2012) Nicotine-induced upregulation of native neuronal nicotinic receptors is caused by multiple mechanisms. J Neurosci 32:2227-2238. CrossRef Medline

Grahame NJ, Cunningham CL (1997) Intravenous ethanol self-administration in C57BL/6J and DBA/2J mice. Alcohol Clin Exp 21: 56-62. CrossRef Medline

Hans M, Wilhelm M, Swandulla D (2012) Menthol suppresses nicotinic acetylcholine receptor functioning in sensory neurons via allosteric modulation. Chem Senses 37:463-469. CrossRef Medline

Harpsøe K, Ahring PK, Christensen JK, Jensen ML, Peters D, Balle T (2011) Unraveling the high- and low-sensitivity agonist responses of nicotinic acetylcholine receptors. J Neurosci 31:10759-10766. CrossRef Medline

Henderson BJ, Lester HA (2015) Inside-out neuropharmacology of nicotinic drugs. Neuropharm 96 (Pt B):178-193. CrossRef Medline

Henderson BJ, Srinivasan R, Nichols WA, Dilworth CN, Gutierrez DF, Mackey ED, McKinney S, Drenan RM, Richards CI, Lester HA (2014) Nicotine exploits a COPI-mediated process for chaperone-mediated upregulation of its receptors. J Gen Physiol 143:51-66. CrossRef Medline

Henley BM, Williams BA, Srinivasan R, Cohen BN, Xiao C, Mackey ED, Wold BJ, Lester HA (2013) Transcriptional regulation by nicotine in dopaminergic neurons. Biochem Pharmacol 86:1074-1083. CrossRef Medline

Huang da W, Sherman BT, Lempicki RA (2009) Systematic and integrative analysis of large gene lists using DAVID bioinformatics resources. Nat Protoc 4:44-57. CrossRef Medline

Ingram SL, Prasad BM, Amara SG (2002) Dopamine transporter-mediated conductances increase excitability of midbrain dopamine neurons. Nat Neurosci 5:971-978. CrossRef Medline

Kuryatov A, Lindstrom J (2011) Expression of functional human $\alpha 6 \beta 2 \beta 3$ acetylcholine receptors in Xenopus laevis oocytes achieved through subunit chimeras and concatamers. Mol Pharmacol 79:126-140. CrossRef Medline

Kuryatov A, Luo J, Cooper J, Lindstrom J (2005) Nicotine acts as a pharmacological chaperone to up-regulate human $\alpha 4 \beta 2$ acetylcholine receptors. Mol Pharmacol 68:1839-1851. Medline

Kuryatov A, Mukherjee J, Lindstrom J (2013) Chemical chaperones exceed the chaperone effects of RIC-3 in promoting assembly of functional $\alpha 7$ AChRs. PloS One 8:e62246. CrossRef Medline

Lester HA, Xiao C, Srinivasan R, Son CD, Miwa J, Pantoja R, Dougherty DA, Banghart MR, Goate AM, Wang JC (2009) Nicotine is a selective pharmacological chaperone of acetylcholine receptor number and stoichiometry. Implications for drug discovery. AAPS J 11:167-177. CrossRef Medline

Liu L, Zhao-Shea R, McIntosh JM, Gardner PD, Tapper AR (2012) Nicotine persistently activates ventral tegmental area dopaminergic neurons via nicotinic acetylcholine receptors containing $\alpha 4$ and $\alpha 6$ subunits. Mol Pharmacol 81:541-548. CrossRef Medline

Mackey ED, Engle SE, Kim MR, O’Neill HC, Wageman CR, Patzlaff NE, Wang Y, Grady SR, McIntosh JM, Marks MJ, Lester HA, Drenan RM (2012) $\alpha 6^{*}$ Nicotinic acetylcholine receptor expression and function in a visual salience circuit. J Neurosci 32:10226-10237. CrossRef Medline

Matta SG, Balfour DJ, Benowitz NL, Boyd RT, Buccafusco JJ, Caggiula AR, Craig CR, Collins AC, Damaj MI, Donny EC, Gardiner PS, Grady SR, Heberlein U, Leonard SS, Levin ED, Lukas RJ, Markou A, Marks MJ, McCallum SE, Parameswaran N, et al. (2007) Guidelines on nicotine dose selection for in vivo research. Psychopharmacology (Berl) 190:269319. CrossRef Medline

McCarthy WJ, Caskey NH, Jarvik ME, Gross TM, Rosenblatt MR, Carpenter C (1995) Menthol vs nonmenthol cigarettes: effects on smoking behavior. Am J Public Health 85:67-72. CrossRef Medline

Moss FJ, Imoukhuede PI, Scott K, Hu J, Jankowsky JL, Quick MW, Lester HA (2009) GABA transporter function, oligomerization state, and anchoring: correlates with subcellularly resolved FRET. J Gen Physiol 134:489521. CrossRef Medline

Mukhin AG, Kimes AS, Chefer SI, Matochik JA, Contoreggi CS, Horti AG, Vaupel DB, Pavlova O, Stein EA (2008) Greater nicotinic acetylcholine receptor density in smokers than in nonsmokers: a PET study with 2-18FFA-85380. J Nucl Med 49:1628-1635. CrossRef Medline

Nashmi R, Dickinson ME, McKinney S, Jareb M, Labarca C, Fraser SE, Lester HA (2003) Assembly of $\alpha 4 \beta 2$ nicotinic acetylcholine receptors assessed with functional fluorescently labeled subunits: effects of localization, trafficking, and nicotine-induced upregulation in clonal mammalian cells and in cultured midbrain neurons. J Neurosci 23:11554-11567. Medline

Nashmi R, Xiao C, Deshpande P, McKinney S, Grady SR, Whiteaker P, Huang Q, McClure-Begley T, Lindstrom JM, Labarca C, Collins AC, Marks MJ, Lester HA (2007) Chronic nicotine cell specifically upregulates functional $\alpha 4^{\star}$ nicotinic receptors: basis for both tolerance in midbrain and enhanced long-term potentiation in perforant path. J Neurosci 27:82028218. CrossRef Medline

Nelson ME, Kuryatov A, Choi CH, Zhou Y, Lindstrom J (2003) Alternate stoichiometries of $\alpha 4 \beta 2$ nicotinic acetylcholine receptors. Mol Pharmacol 63:332-341. CrossRef Medline

Nichols WA, Henderson BJ, Yu C, Parker RL, Richards CI, Lester HA, Miwa JM (2014) Lynx1 shifts $\alpha 4 \beta 2$ nicotinic receptor subunit stoichiometry by affecting assembly in the endoplasmic reticulum. J Biol Chem 289: 31423-31432. CrossRef Medline

Richards CI, Srinivasan R, Xiao C, Mackey ED, Miwa JM, Lester HA (2011) Trafficking of $\alpha 4^{\star}$ nicotinic receptors revealed by superecliptic phluorin: effects of a $\beta 4$ amyotrophic lateral sclerosis-associated mutation and chronic exposure to nicotine. J Biol Chem 286:31241-31249. CrossRef Medline

Richards CI, Luong K, Srinivasan R, Turner SW, Dougherty DA, Korlach J, Lester HA (2012) Live-cell imaging of single receptor composition using zero-mode waveguide nanostructures. Nano Lett 12:3690-3694. CrossRef Medline

Rodgman A, Perfetti TA (2009) The chemical components of tobacco and tobacco smoke. Boca Raton, FL: CRC.

Sallette J, Pons S, Devillers-Thiery A, Soudant M, Prado de Carvalho L, Changeux JP, Corringer PJ (2005) Nicotine upregulates its own receptors through enhanced intracellular maturation. Neuron 46:595-607. CrossRef Medline

Shih PY, Engle SE, Oh G, Deshpande P, Puskar NL, Lester HA, Drenan RM (2014) Differential expression and function of nicotinic acetylcholine receptors in subdivisions of medial habenula. J Neurosci 34:9789-9802. CrossRef Medline

Sine SM, Claudio T, Sigworth FJ (1990) Activation of Torpedo acetylcholine receptors expressed in mouse fibroblasts. J Gen Physiol 96:395-437. CrossRef Medline

Son CD, Moss FJ, Cohen BN, Lester HA (2009) Nicotine normalizes intracellular subunit stoichiometry of nicotinic receptors carrying mutations linked to autosomal dominant nocturnal frontal lobe epilepsy. Mol Pharmacol 75:1137-1148. CrossRef Medline

Srinivasan R, Pantoja R, Moss FJ, Mackey ED, Son CD, Miwa J, Lester HA (2011) Nicotine upregulates $\alpha 4 \beta 2$ nicotinic receptors and ER exit sites via stoichiometry-dependent chaperoning. J Gen Physiol 137:59-79. CrossRef Medline

Srinivasan R, Richards CI, Xiao C, Rhee D, Pantoja R, Dougherty DA, Miwa JM, Lester HA (2012) Pharmacological chaperoning of nicotinic acetylcholine receptors reduces the endoplasmic reticulum stress response. Mol Pharmacol 81:759-769. CrossRef Medline

Srinivasan R, Henley BM, Henderson BJ, Henley B, Indersmitten T, Cohen BN, Kim CH, McKinney S, Deshpande P, Xiao C, Lester HA (2016) Smoking-relevant nicotine concentration attenuates the unfolded protein response in dopaminergic neurons. J Neurosci 36:65-79. CrossRef Medline

Staley JK, Krishnan-Sarin S, Cosgrove KP, Krantzler E, Frohlich E, Perry E, Dubin JA, Estok K, Brenner E, Baldwin RM, Tamagnan GD, Seibyl JP, Jatlow P, Picciotto MR, London ED, O'Malley S, van Dyck CH (2006) Human tobacco smokers in early abstinence have higher levels of $\beta 2^{*}$ nicotinic acetylcholine receptors than nonsmokers. J Neurosci 26:87078714. CrossRef Medline

Sulzer D (2011) How addictive drugs disrupt presynaptic dopamine neurotransmission. Neuron 69:628-649. CrossRef Medline

Tapper AR, McKinney SL, Nashmi R, Schwarz J, Deshpande P, Labarca C, Whiteaker P, Marks MJ, Collins AC, Lester HA (2004) Nicotine activation of $\alpha 4^{*}$ receptors: sufficient for reward, tolerance and sensitization. Science 306:1029-1032. CrossRef Medline

Ton HT, Smart AE, Aguilar BL, Olson TT, Kellar KJ, Ahern GP (2015) Men- 
thol enhances the desensitization of human $\alpha 3 \beta 4$ nicotinic acetylcholine receptors. Mol Pharmacol 88:256-264. CrossRef Medline

Tumkosit P, Kuryatov A, Luo J, Lindstrom J (2006) $\beta 3$ Subunits promote expression and nicotine-induced up-regulation of human nicotinic $\alpha 6^{*}$ nicotinic acetylcholine receptors expressed in transfected cell lines. Mol Pharmacol 70:1358-1368. CrossRef Medline

Vallejo YF, Buisson B, Bertrand D, Green WN (2005) Chronic nicotine exposure upregulates nicotinic receptors by a novel mechanism. J Neurosci 25:5563-5572. CrossRef Medline

Wang J, Kuryatov A, Sriram A, Jin Z, Kamenecka TM, Kenny PJ, Lindstrom J (2015) An accessory agonist binding site promotes activation of $\alpha 4 \beta 2^{\star}$ nicotinic acetylcholine receptors. J Biol Chem 290:13907-13918. CrossRef Medline

Wang T, Wang B, Chen H (2014) Menthol facilitates the intravenous selfadministration of nicotine in rats. Front Behav Neurosci 8:437. CrossRef Medline

Whiteaker P, Sharples CG, Wonnacott S (1998) Agonist-induced upregulation of $\alpha 4 \beta 2$ nicotinic acetylcholine receptors in M10 cells: pharmacological and spatial definition. Mol Pharmacol 53:950-962. Medline
World Health Organization (2008) Report on the global tobacco epidemic. The MPOWER package. Geneva: World Health Organization.

Xiao C, Nashmi R, McKinney S, Cai H, McIntosh JM, Lester HA (2009) Chronic nicotine selectively enhances $\alpha 4 \beta 2^{*}$ nicotinic acetylcholine receptors in the nigrostriatal dopamine pathway. J Neurosci 29:12428 12439. CrossRef Medline

Xiao C, Srinivasan R, Drenan RM, Mackey ED, McIntosh JM, Lester HA (2011) Characterizing functional $\alpha 6 \beta 2$ nicotinic acetylcholine receptors in vitro: mutant $\beta 2$ subunits improve membrane expression, and fluorescent proteins reveal responsive cells. Biochem Pharmacol 82:852-861. CrossRef Medline

Yang JS, Valente C, Polishchuk RS, Turacchio G, Layre E, Moody DB, Leslie CC, Gelb MH, Brown WJ, Corda D, Luini A, Hsu VW (2011) COPI acts in both vesicular and tubular transport. Nat Cell Biol 13:996-1003. CrossRef Medline

Ye JH, Zhang J, Xiao C, Kong JQ (2006) Patch-clamp studies in the CNS illustrate a simple new method for obtaining viable neurons in rat brain slices: glycerol replacement of $\mathrm{NaCl}$ protects CNS neurons. J Neurosci Methods 158:251-259. CrossRef Medline 